فاعلية برنامج تدريبي التنمية بعض مهار اتجات

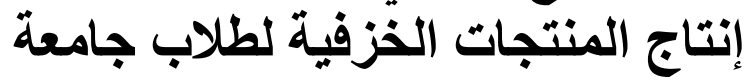
بورسعيد كمدخل للاتجاه نحو المشروعات الصغيرة

The Effectiveness of a training program for the development of the skills of some of the production of ceramic products of Port Said - University Students as an approach to a trend towards small projects

(عداد

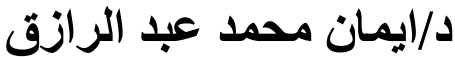

مدرس الخزف بقسم التربية الفنية كلية التربية النوعية

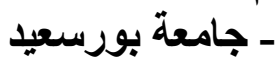

الحياتية اليومية النفعية والجمالية،الأمر الذي

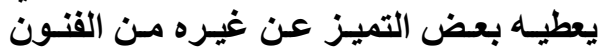

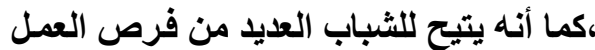

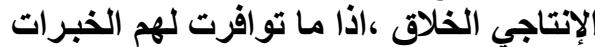

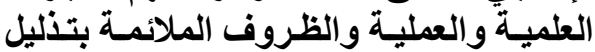

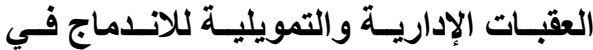

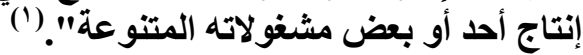

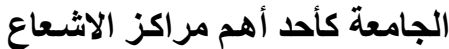

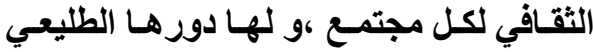

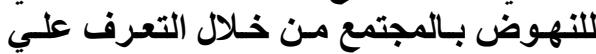

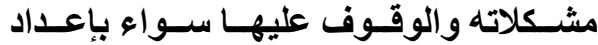
البـرامج والانشـطة المختلفـة، والتـي تعـالج

1_ـطه يوسف طه في 2006؛: الدور التتموي للخرف

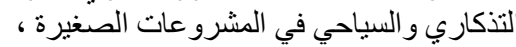
المؤتمر العلمي التاسع، كلية التربية الفنية ،جامعة التران

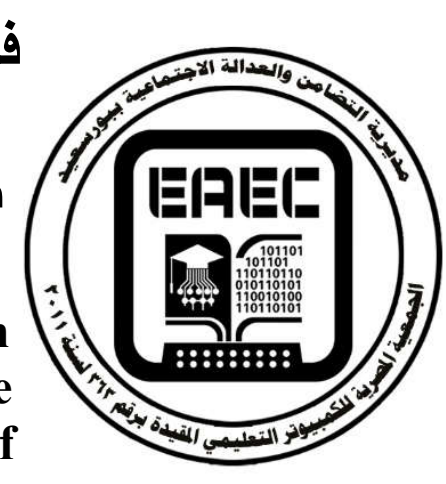

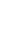


قامــت الباحثــة بتجريسـب برنـــامج تــــــيبي

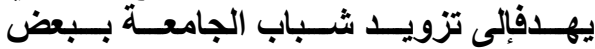

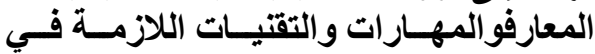

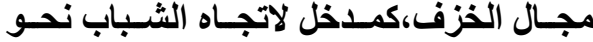

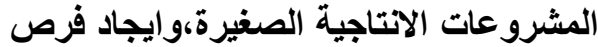
عمل وأفكار جديدة يمكن الاستفادة منهـا فئي

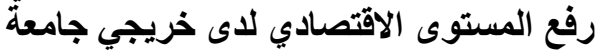

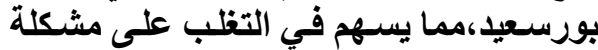

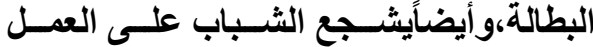

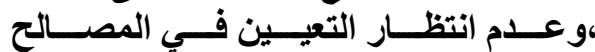

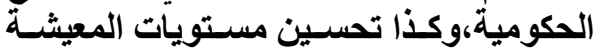

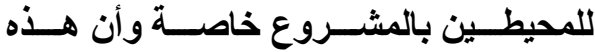

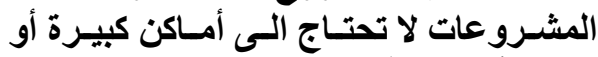

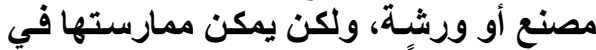

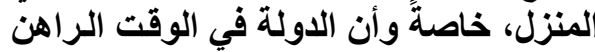

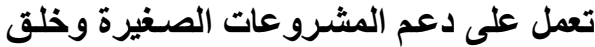

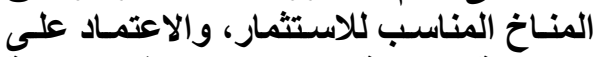

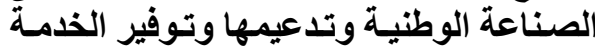
اللازمة لنمو هذه المشروعات المنات مشكلة البحث: المزو هذه

التنميــة الاجتمـاعيـة سـتنظل دائمــاً

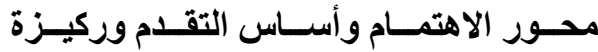

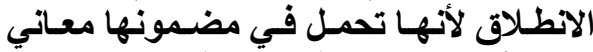

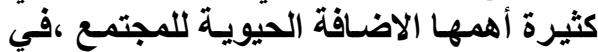

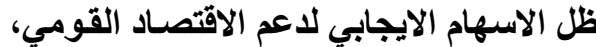

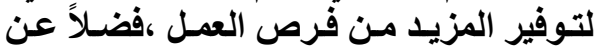

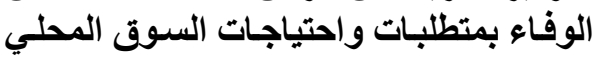

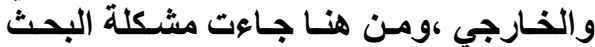
وتتحدد في التساؤل التالية:

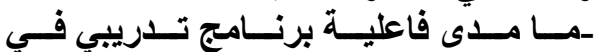

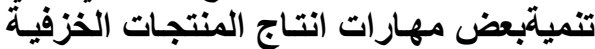

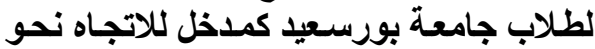
المشروعات الصغيرة؟

ويتفرع من هذا السؤال التساؤلات التالية:

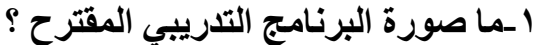

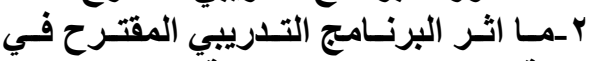

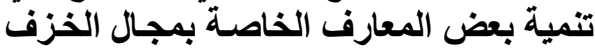

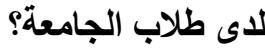

فيهـا أهـم قضـايـاه الاجتمـاعيـة ،أو مـن خـلال

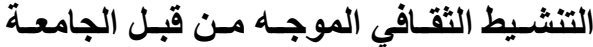

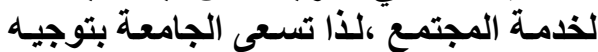

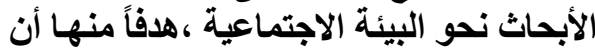

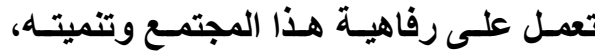

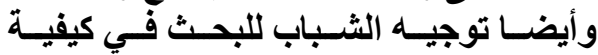

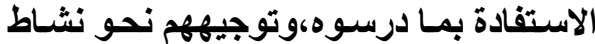

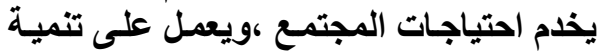

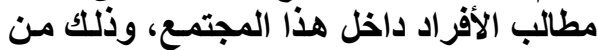

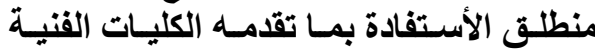

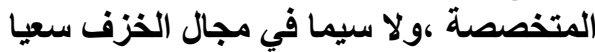

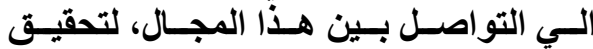
المتطلبات العصرية للمجتمع.

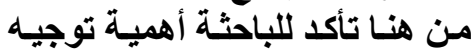

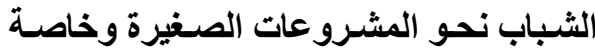

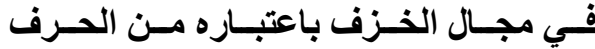

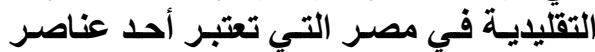

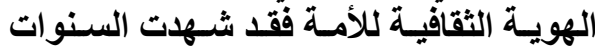

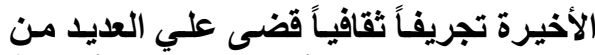

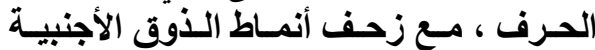
وغزو المنتجـات الحرفيـة للأسـواق المحليـة

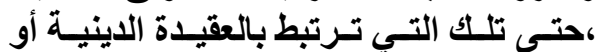
بمظاهر الحياة الاجتماعية.

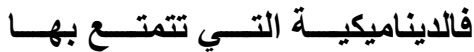

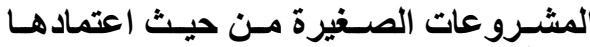

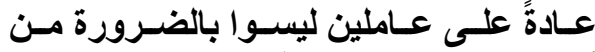

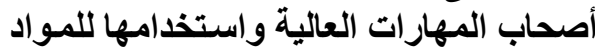

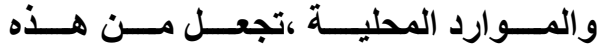

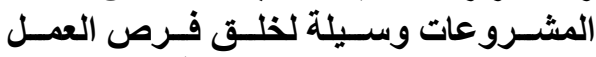

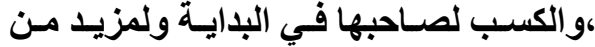

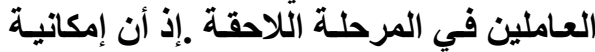

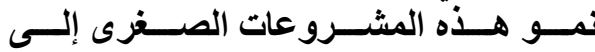
مشروعات متوسطة هي امكاتية كبيرة، وان

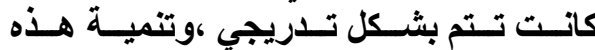
المشروعات يعنى في النهايتة استخدام مزيــ

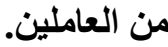
وانطلاقاً من هذا وإيماناً من الباحثة

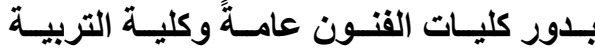

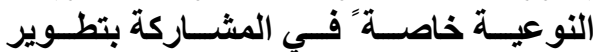

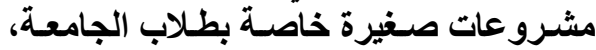


1 أختبار تحصيلي لقياس الجوانب المعرفية و الفنية في مجال الخزف. r-معيار لتحكيم الجوانب المهاريـة في مجال

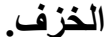

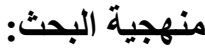
يتبع البحث المنهج الوصفي التحليلي ،حيث

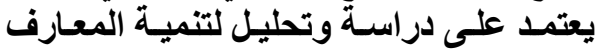

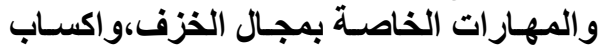
طلاب الجامعة بعض الخبرات اللازمـة لإدارة المشروعات الصغيرة. كما يتبع البحث المنهج التجريبي، عند أجراء الجاتب العملي التطبيقي للبحث.

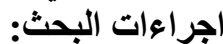

اولأ_الجاتب النظري ،ويتضــن عدة محساور

ـالمحسور الاول:التعـرف علــى مجــال

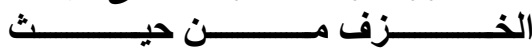

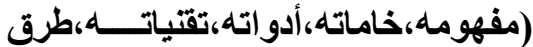
تلوينه ، تسويه........). ـالمحسور الثاني: تنميـة القدرات القنيـة و التقنية لطلاب جامعة بورسعيد. ـالمحور الثالث: اكسـاب طلاب الجامعة بوريعة بعض الخبرات التسويقية. مصطلحات البحث:

برنامج تدريب: ProgramTraining يعرف البرنامج التدريبي علي أنها: هو الجها

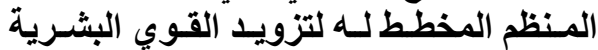

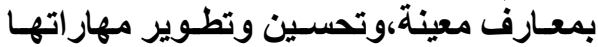
وقــراتها وتغييـر سـلـوكها اتجاهاتهـا بشـكل ايجابي بناء.

ويعرفِ ايضـاً على أنها جهـ تنظيمي مخطط يهدف لتسـهيل اكتسـاب المتلدربين المهارات

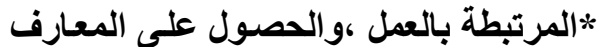

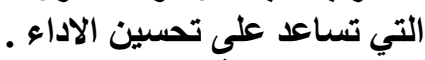

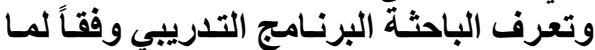

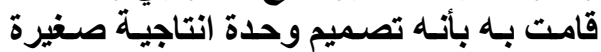

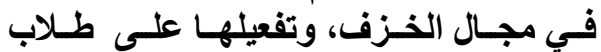

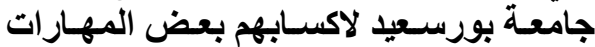

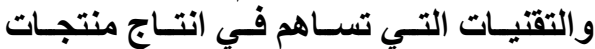

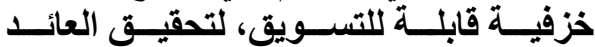

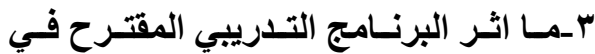

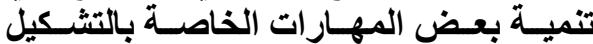
الخزفي لاى طلاب الجامعة؟

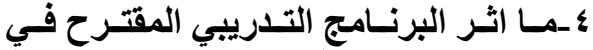

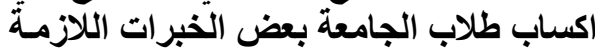

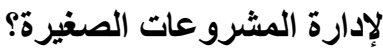

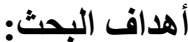
اـتنميـة بعض المبـة المهارات المعرفيـة والفنيـة

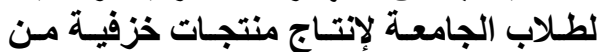
خلال برنامج تدريبي مقنت.

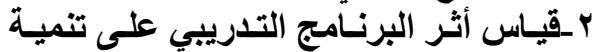

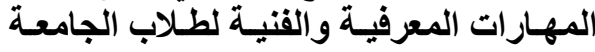

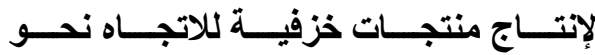
المشروعات الصغيرة . لأبات

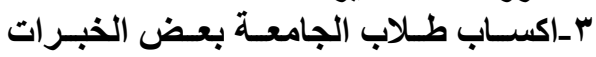
اللازمة لإدارةالمشروعات الجات الصغيرة.

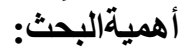

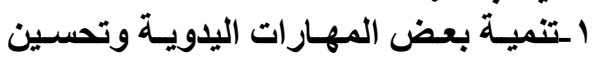

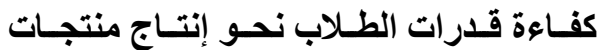

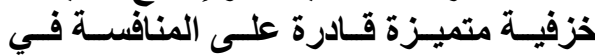
البوق المحلي و الإقليمي و العالمي.

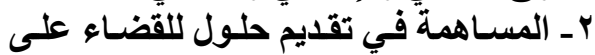
البطالة واستغلال خبرات وإمكاتيات الثبات الثباب.

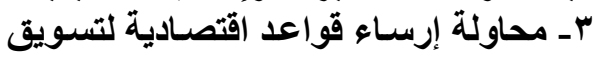

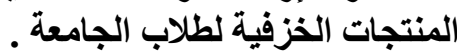

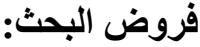
يفترض البحث أنه:

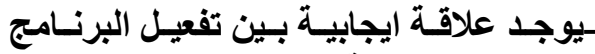

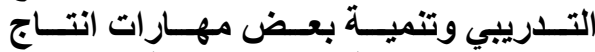

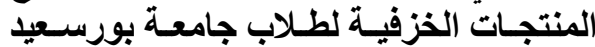

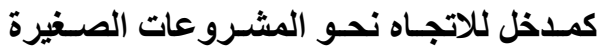
، وذلك من خلال الاتي:

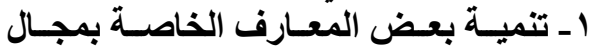
الخزف لدي طلاب الجامعة.

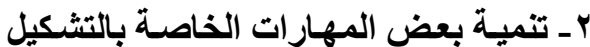
الخزفي لابى طلاب الجامعة.

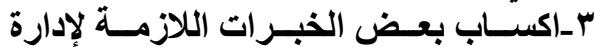
المشروعات الصغيرة لاى طلاب الجامعة.

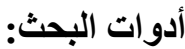


وتميزها من ناحية اخرى، مما يشكل عنصرا

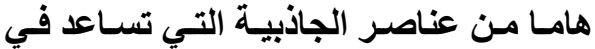
سهولة التسويق ،اما من حيث التشكيل فهيـا

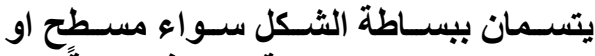

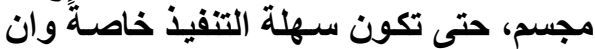
غالبية الطلاب من غير دارسي الفن، ونتميز

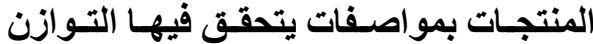

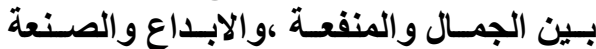

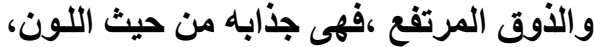

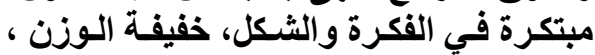

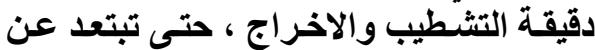

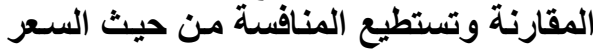
وتتوع وتعدد الاشكال والوظائف. ـالمشروعات الصغيرة:(small projects)

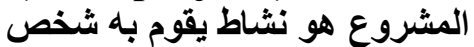

ما باتنظام ،من اجل كسب المسال، ويقدم شئئًاً

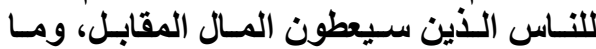

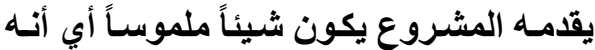

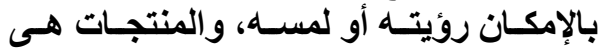

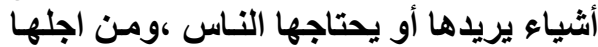
يرغبون في دفع المال.

فهو عملية استثمار يتم من خلال فلها

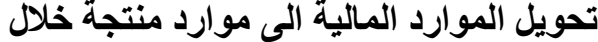

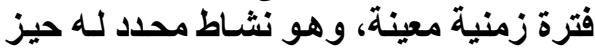

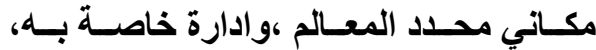

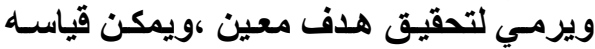
من حيث تكاليفه وعو لتئ هدوائده.
الاقتصـادي المتميز للشبـاب الجـامعي ،وفي تلوفي

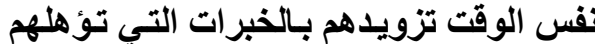

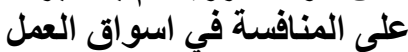

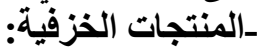

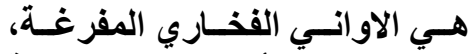

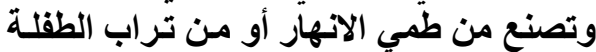

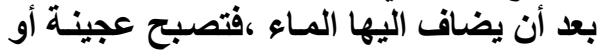

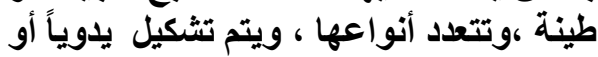

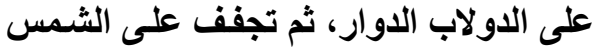

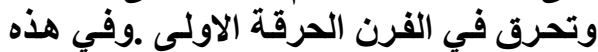

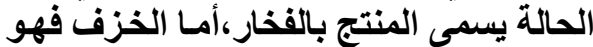

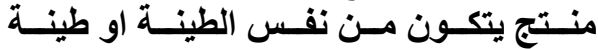

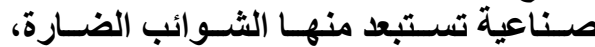

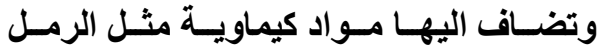

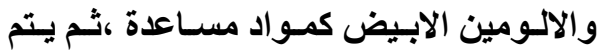
تلوينه وزخرفته بطلاء زجاجى يسمى الجليز الإنيز

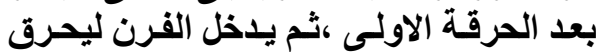
الحرقة الثانية ،وفي هذه الحالة الحئ يسمى المنتج والمنتجات الخزفية في هذه التجربة بالخزف'

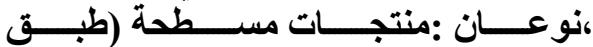

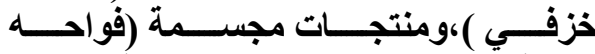
خزفية)،تستند في تصميمها ومعالجة سطحها

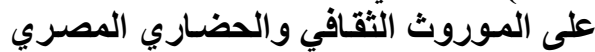
،لتؤكد هويتها من ناحية ويستمد منه فرادتها

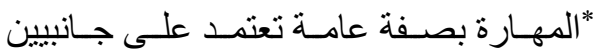

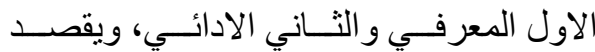

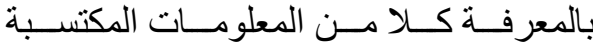

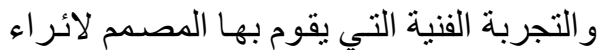

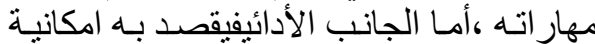
التنفيذ لهذه المعر فتنقلا عن: التهان: austin-1995: apparel and textile production reference :book texas technical niversity home economics curriculum center -

p.34.

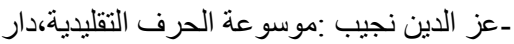

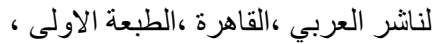

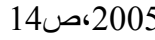




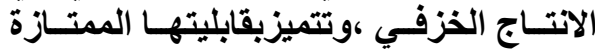

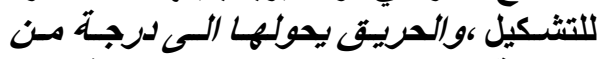
الصلابة وقوة التحمل ،وهي موجودة في كل كل

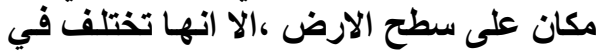

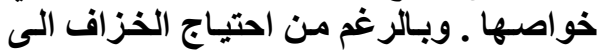

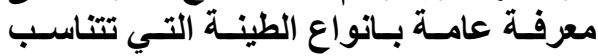

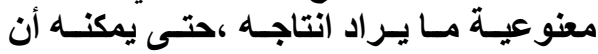

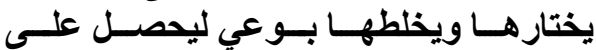

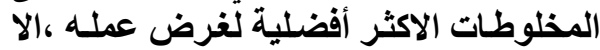

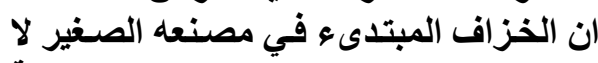

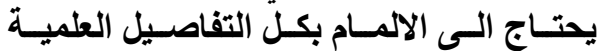

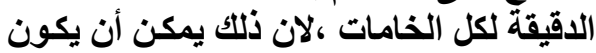

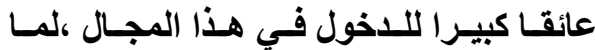

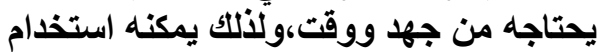
الطينـات التجاريـة الجـاهزة للانتـاج بتركييتهـا

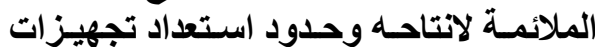

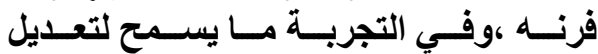
التركيبات القياسية ليحصل على نتائج معينة

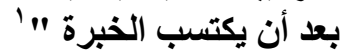

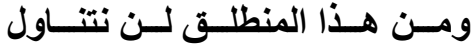
الطينـات في هذا البحث بأنواعهـا وتركيبهـا

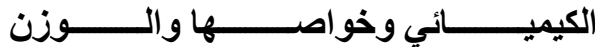

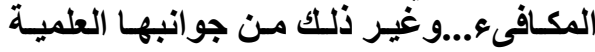

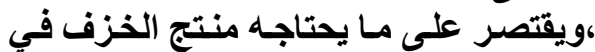

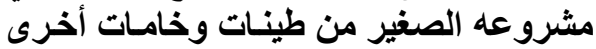

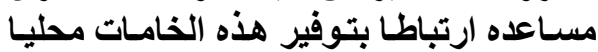
وبأسعار مناسبة أباطة

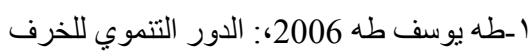

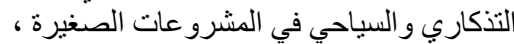

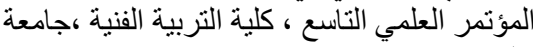
حلوان، صن العبري
} 


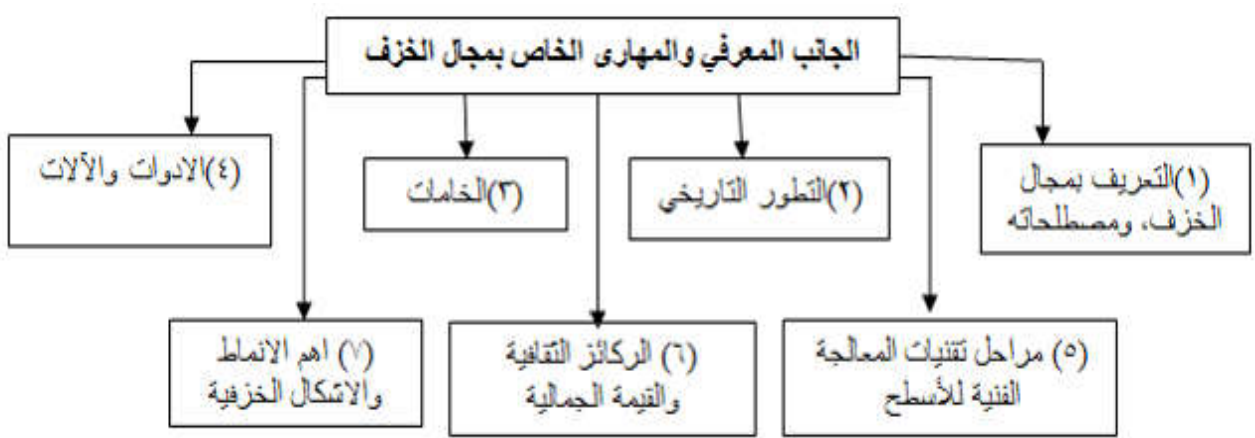

مخطط (1) يوضح الجانب المعرفي والمهارث للبرنامج النكريبي المقترح، من انتاج الباحثة

المحور الثاني: تنمية القدرات الفنية والتقنية

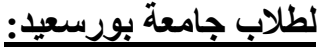

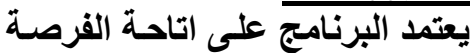

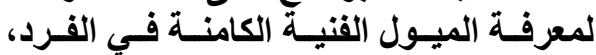

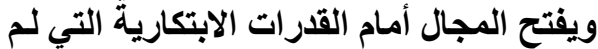
تكتشف بعد، وذلتك عن طريق استخدام التخات التخيل

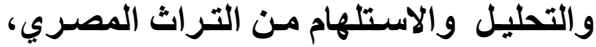

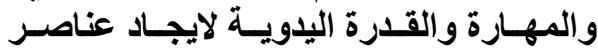

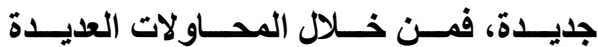
الاستكشافية يكتسب الطالب امكانيات جديدة

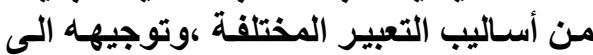

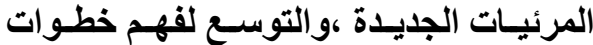

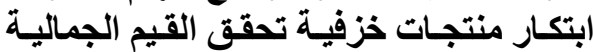
على أسس عملية سليمة تعتمد في دراستها فئها

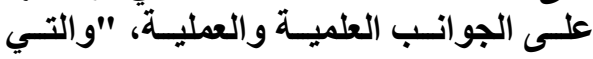
تعتمد بلورها على التجريب من خلانل جانبين

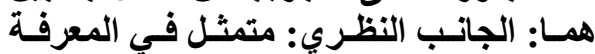
(knowledge) (الجاتب العملي: متمثل في في المعلي 'المهارة (skill) 


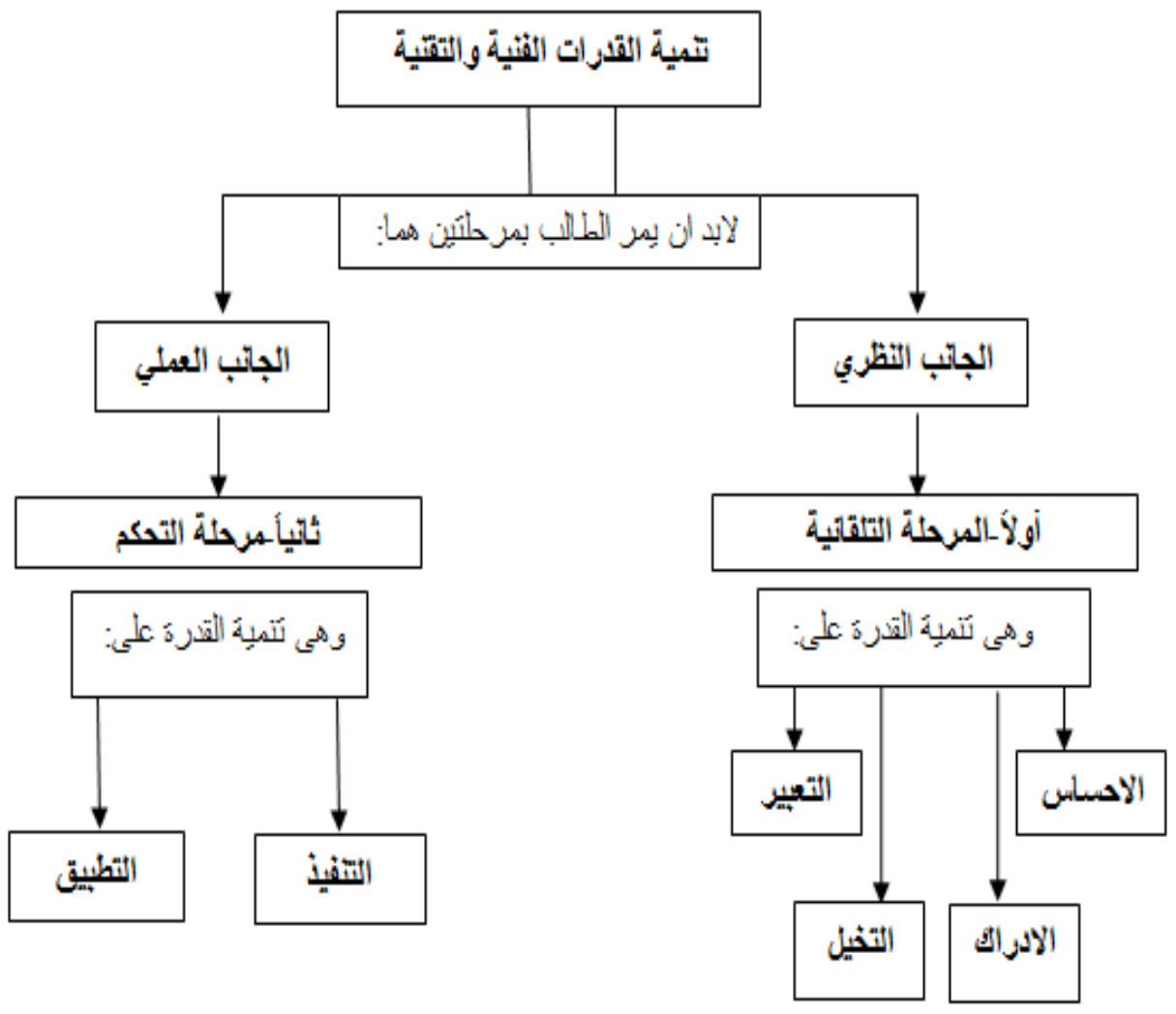

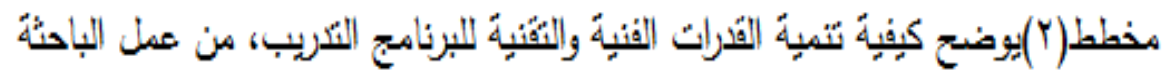

مـع تغيرات السوق ،فضلاً عن أن"استثمار

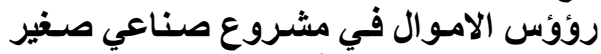

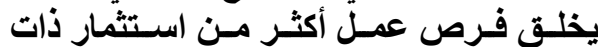

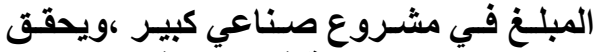
بالتالي مجالات واسعة في تؤيليد فرص العبر العدل

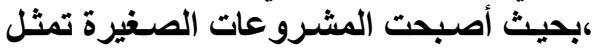
مستودعا لفرص العمـل الجديدة ،وأداة مـن تمن
المحور الثالث :اكسـاب طلاب الجامعة بعض الخبرات التسويقية:

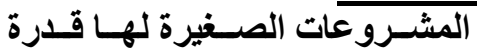

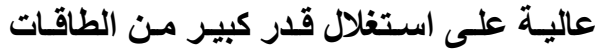

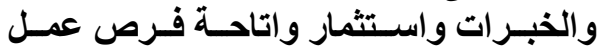

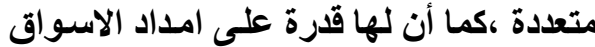

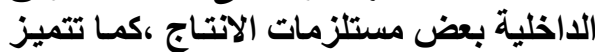

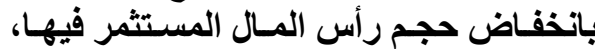

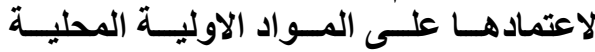

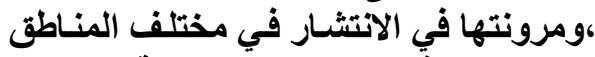

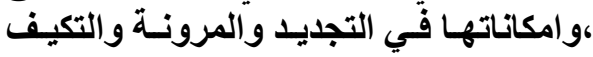


المحلي والاقليمي ،من خلال توفير البيئة

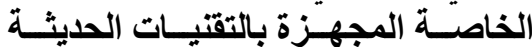
والمعدات التكنولوجية التي تمكنهم من تحويـلـل افكـارهم الـي منتجـــات يمكـن تسويقها. الاستفادة من جميع الخبرات والامكانـات

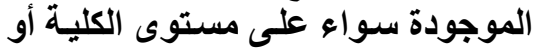

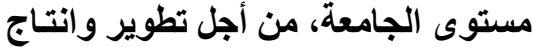
الحدول التقنية الصناعية، وفقاً لمعايير التياج الجودة العالمية.

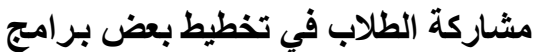

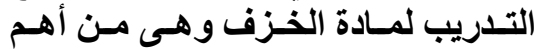

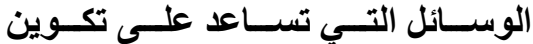
شخصـيتهم واعطـائهم المجــال لتحقيـق

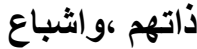
حاجاتهم وتتمية قدراتهمو استعداداتهم.

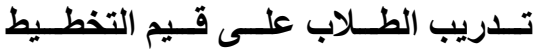

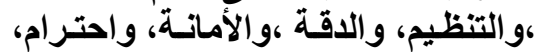

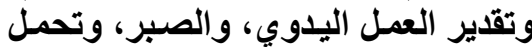

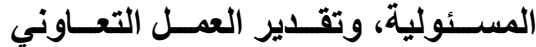

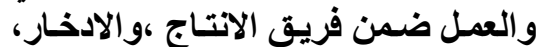

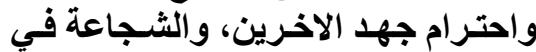
مواجهـة الصـــاب، والابـــاع والابتكــار

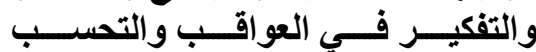

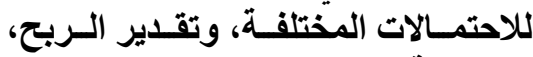
ومواجهة مخاطر الخسارة.

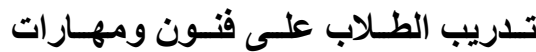
الاعمال التجارية كالتفاوض، والتون والتسويق

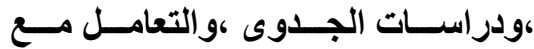

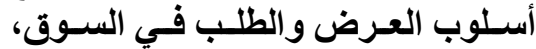

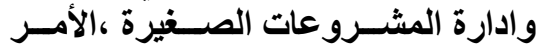

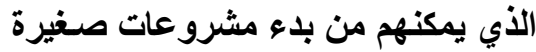
بعد تخرجهم. التعاون ميع الهيئات و والمنظمـات القائمسة بالمجتمع ،لتحقيق الاهداف، والاستفات والمنادة التربوية المنشودة من اعداد الخريجين والئين

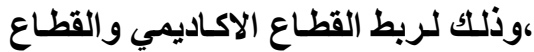

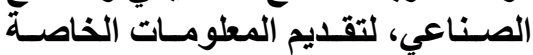

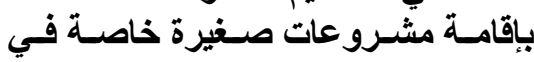

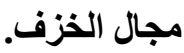

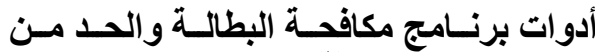
العمل غير المنظم" (1) وتثـــل الخبرة التسـويقية دراســة

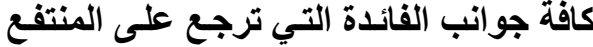

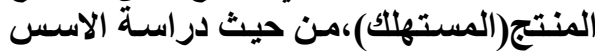
التسويقية للمنتج الفني وهى سـعر المنتجن، كيفيـة الترويج لذه، توزيعـه، دراسـة السـوق،

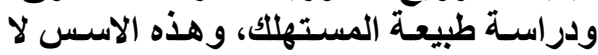

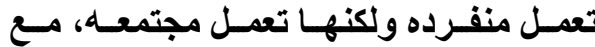

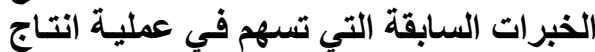

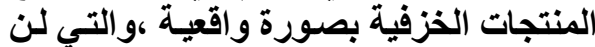
تتحقق الا في ظل ممارسة وتداولئه ويتم تفعيل الكفاءات التسويقية للمنتجات من فئل خلال مجموعة من النقاط هم:

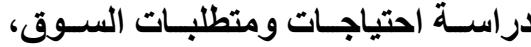

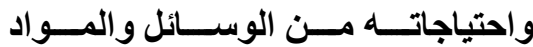
ووالتقتيات المتطورة ،تجنباً لهـر المـال والجها والوقت . اختيـار المـواد والخامسـات الملائمسة في في

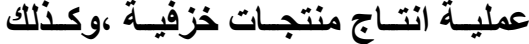
استخذام الخامات المتوفرة محلياً.

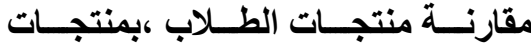

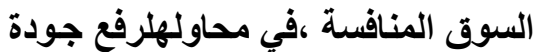
المنتجات الخزفية التي ينتجها الطلاب ـ في فئود

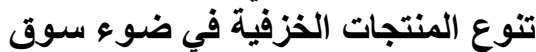
العمل ،حتى تلقى مكاناً للترويج. الأخذ في الاعتبار بالأسس التسرويقية

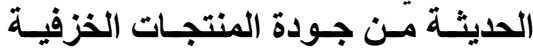

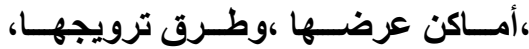
ونوعية وذوق المستهلك.

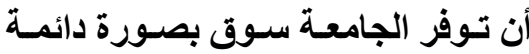
لمنتجات الطلاب في كافة الأعمال الفنية

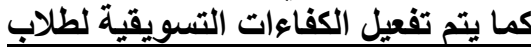

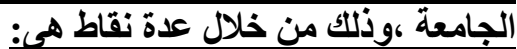

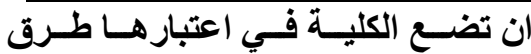

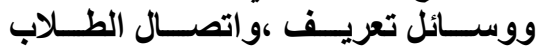
بدراسـة احتيـاج ومتطلبـات سـوق العـل

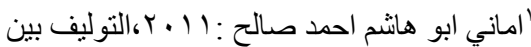

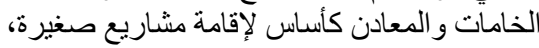

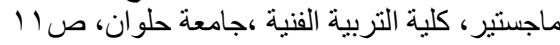




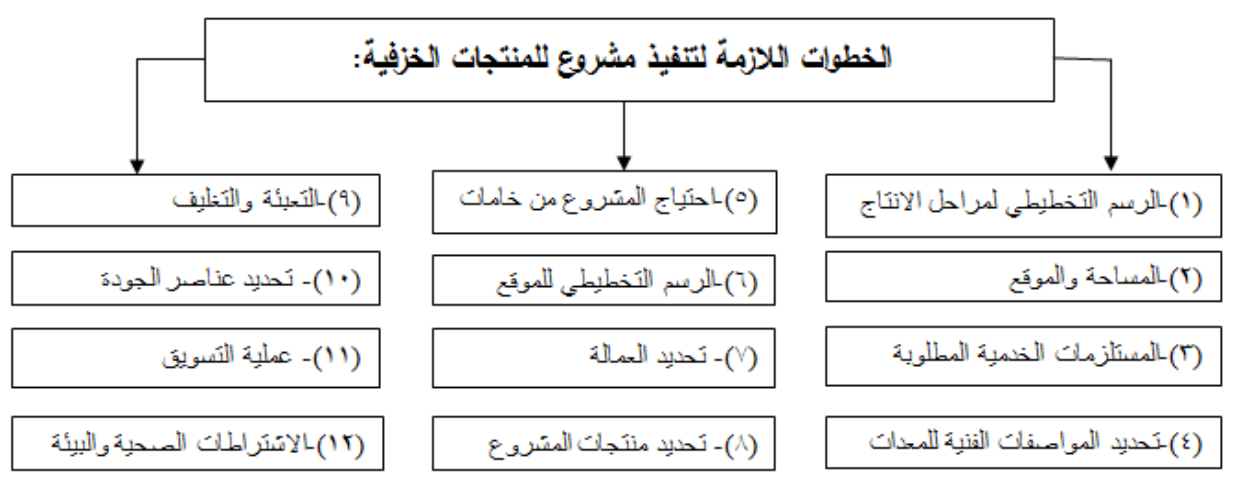

مخطط(r) يوضح الخطوات الازمة لنتفيذ مشروع صغير في مجال الخزف، من انتاج الباحثة

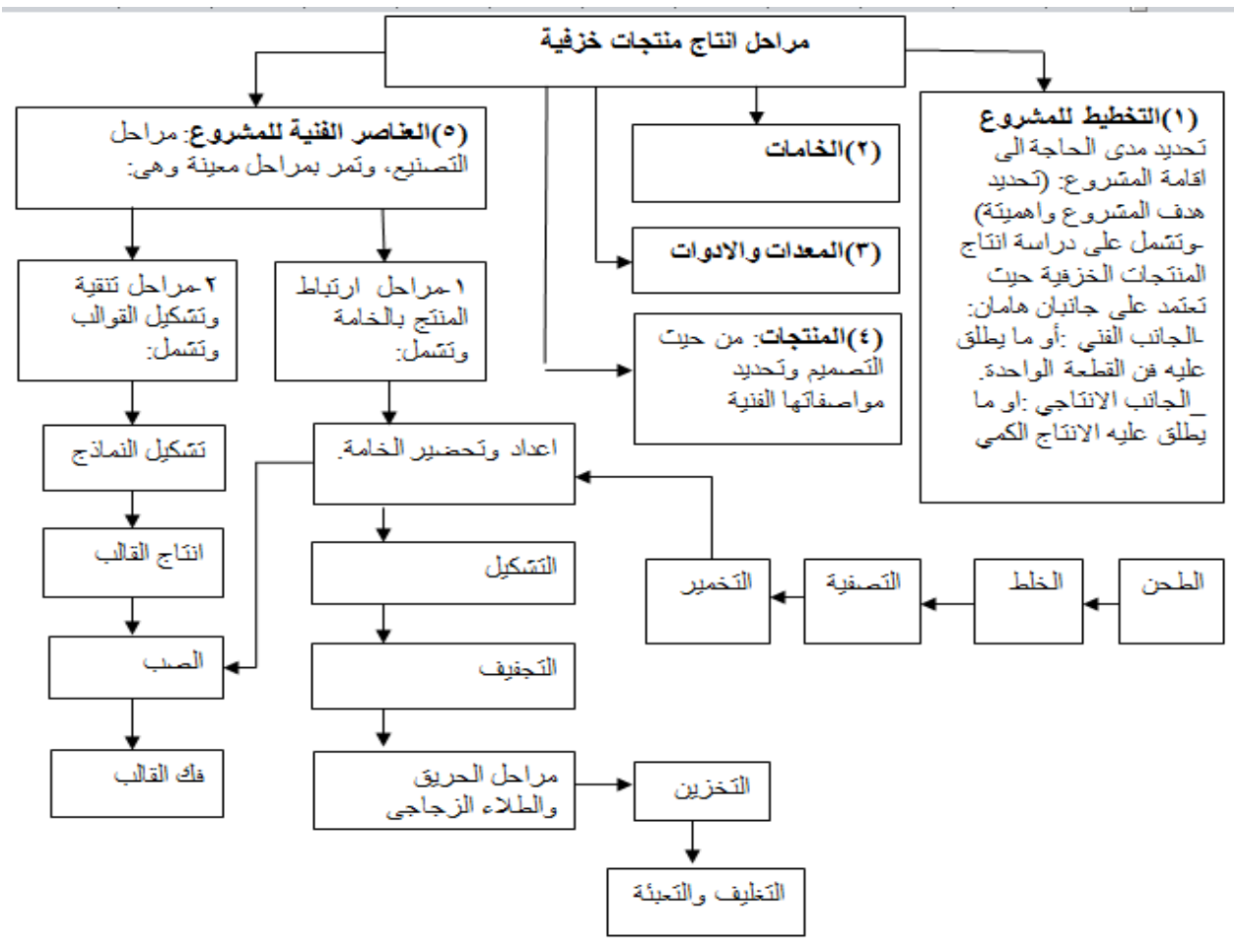

مخطط ( ؛)يوضح أهم مراحل الانتاج الخزفي، من انتاج الباحثة

سلسلة دراسات وبحوث مُحكُمَة .. عدد خاص بالبحوث المحكمة في المؤتمر العلمي الثالث ه 1 ـ ب 


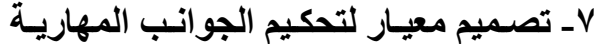
لإتتاج المنتجات الخزفية والتحقق من صديم التص

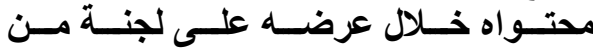
المتخصصين وتعديله وفق آراء اللجنة.

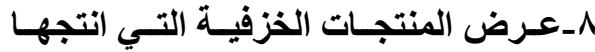
الطلاب على لجنة من المتخصصين التحكيمها في ضوء بنود معيار التحكيم. 9-تحليـل النتـائج تحـــيلاً احصـائياً ونسـبياً للتحقق من صدق فرض البحث.

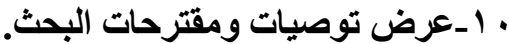

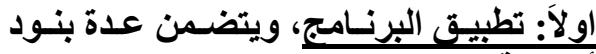

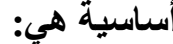

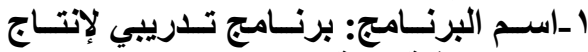
منتجات خزفية قابلة للتسويق البرني ب بقلنفة البرنامج: تتبلور في امكانيـة تفعيل برنامج تدريبي لتنمية بعض ألمهارئية التهات الفنية

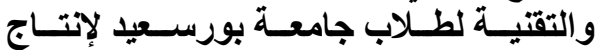

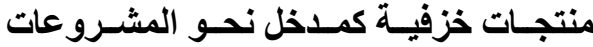
الصغيرة، معتمدة على أربعة عناصر هي:

\section{-القائم بالتّريب(المدرب)}

\section{سموق العلل(المُّرعات الصفرِرة)}

التعـرف علـي محتويـات البرنـامج فـي اطاره النظري والعملي.

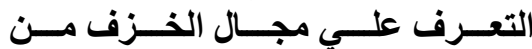
حيث (مفهومها وخاماته و أدواته ومعداتهـ

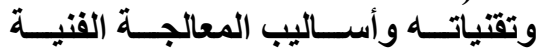
للأسطح وعملية (الحريق)

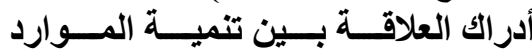
البشرية، وتحقيق التنمية الاقتصادية من خلال المشروعات الصغيرة.

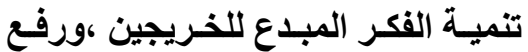

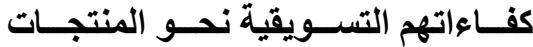
الفنية .
ثنانيـاً: الجانبالعمليللبحــث (التجربـة البحثيـة) وويثـتمل على الخطـوات الاجرائيسة للبحـث وهى:

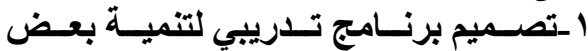

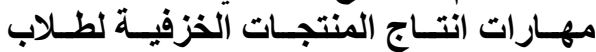

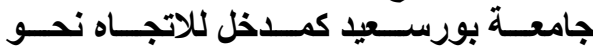
المشروعات الصغيرة.

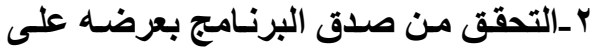

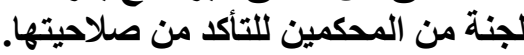

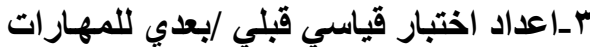

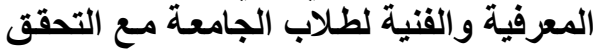

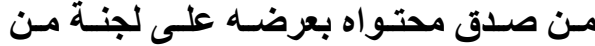
المحكمين وتعديله وفق ما جاء هاء من آراء.

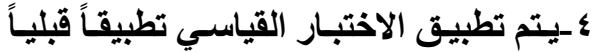

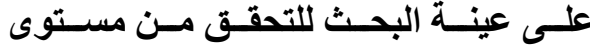

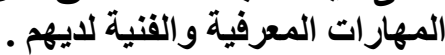
هـتلدريب عينة البحث على مكونـات البرنـامج التدريبي في مجال الخزف. 1ـ تطبيق ألاختبار القياسي على عينة البحث تطبيقاً بعدياً.

\section{-}

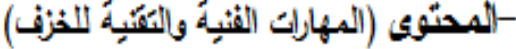

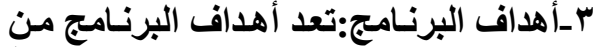

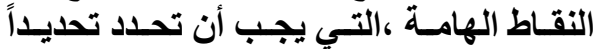

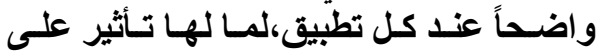

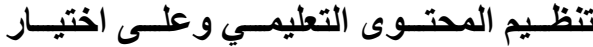

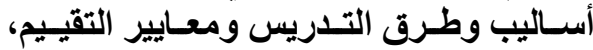

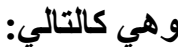

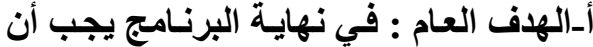
يكون كل طالب قادر على أنتاج أثكال خزفية (نفعية، جمالية) قابلة للتسويق. ب-الأهداف الإجرائية :وتنقسم إلي: الاهداف المعرفية،وتتمثل في: الاجي: 
اكسـاب المتــربين قيمـاً ايجابيـة خاصـة بسوق العمل، والتي تتناسب مـع الخزف الخف

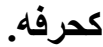
ع أحدود التطبيق العملي للبرنامج: أتتحديد عينة الدراسة :

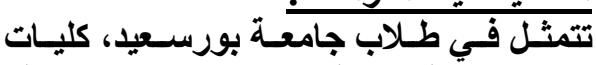
متعددة(تربية نوعية_تجارة _علوم- صيلئلة رياض اطفال -معهد حاسب آلي-معهد خدمئة

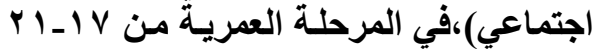
سنة وتم أختيار هم عن طريق نثر النمر اعلان في

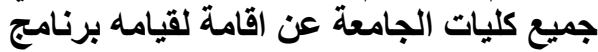

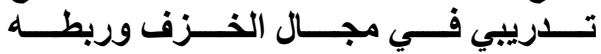

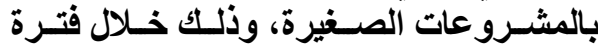

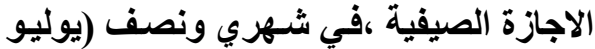
وأغسطس و النصف الاول من سبت سبتمبر)سنة

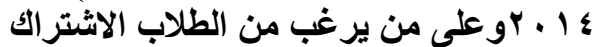

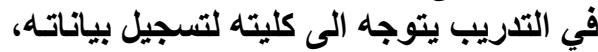

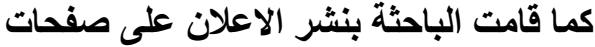

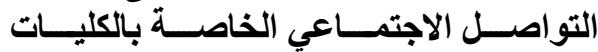
والجامعة، ضماناً لوصول الإعلان لأكبر عدد الطد

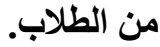

بـمكان التطبيق التجريبى للبرنامج:

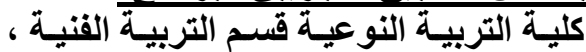
آتيلية الخزف،لاعتباره مجهز لتريس التريس المادة.

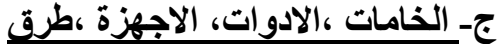
التشثيل ،و الوسائل التعليمية المستخدمة الإنية بالبرنامج التّريبي:
الاهداف المهارية،وتتضمن: اتقــان المتـدربين على مهـارات تجهيـز الطينـات ،التقنيـات ،واســتخدام الادوات ،والتلوين والحريق. التـدريب علـي روئيسة الأسـس الجماليـة

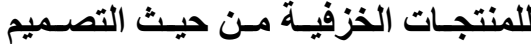
،التنفيذ ،معالجة السطح والتثطيب فنياً وجمالياً. التدريب علي عمل تصميمات لمنتجـات

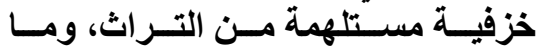
تتضمنه من ابداعات . التدريب علي بعض تقنيات الخزف من بن بات

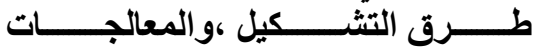

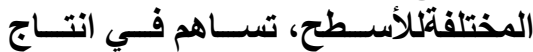
منتجـات خزفيـة ذات طـابع فنـي متميـز تجمع بين الجانبين الوظيفي والجمالي. انتـاج منتجـات خزفيـة مختلفة التئة التقنيـات

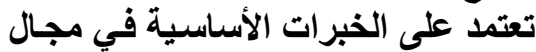

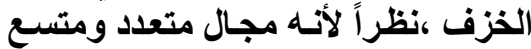
في الجوانب العلمية والتطبيقية. الاهداف الوجدانية ،وتثتنمل على:

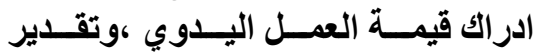

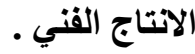

الاسـتفادة مـن القيم القنيـة والجماليــة للتراث ،باعتبـاره مصدراً من المصسادر

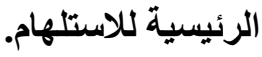

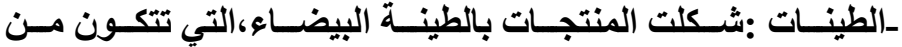

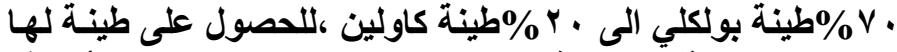

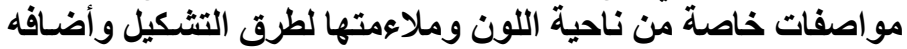

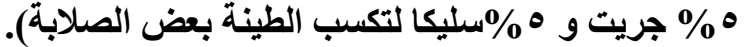

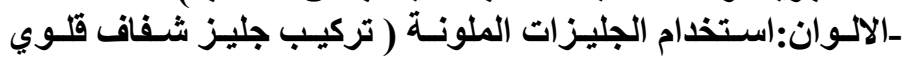




\begin{tabular}{|c|c|}
\hline 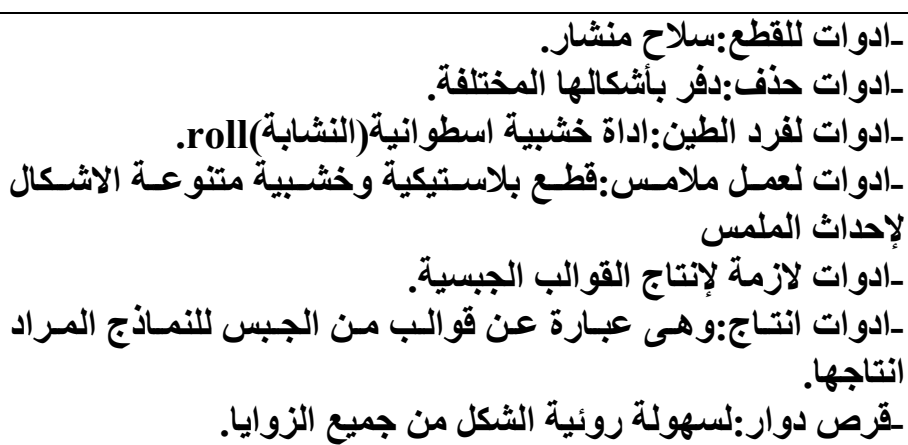 & (ץ) الادوات \\
\hline 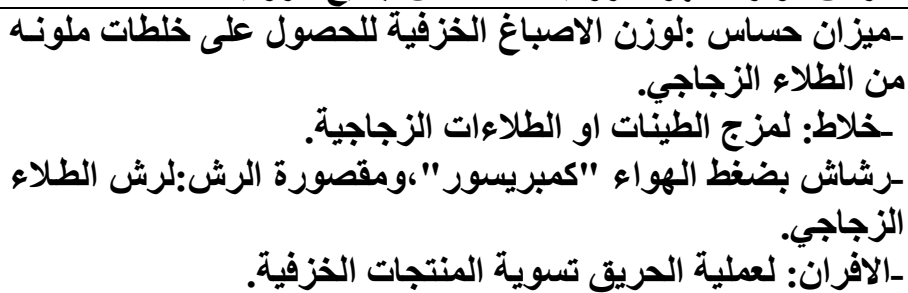 & (r) الاجهزة \\
\hline 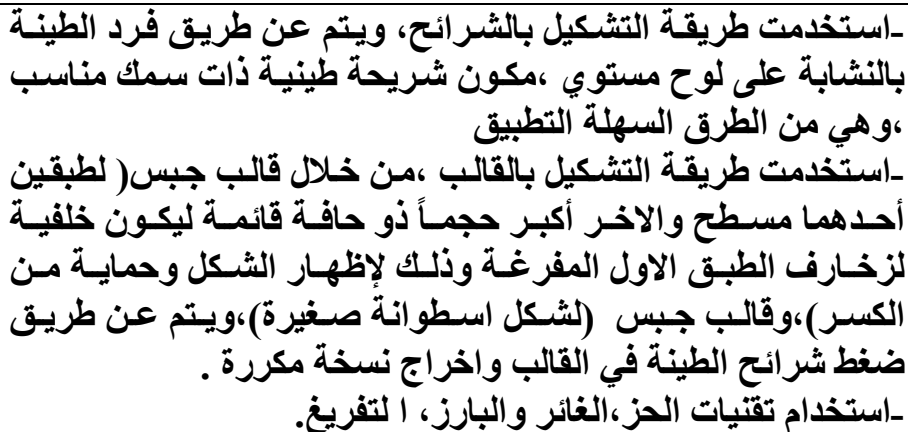 & اللفتيطح:) المعالجــات \\
\hline 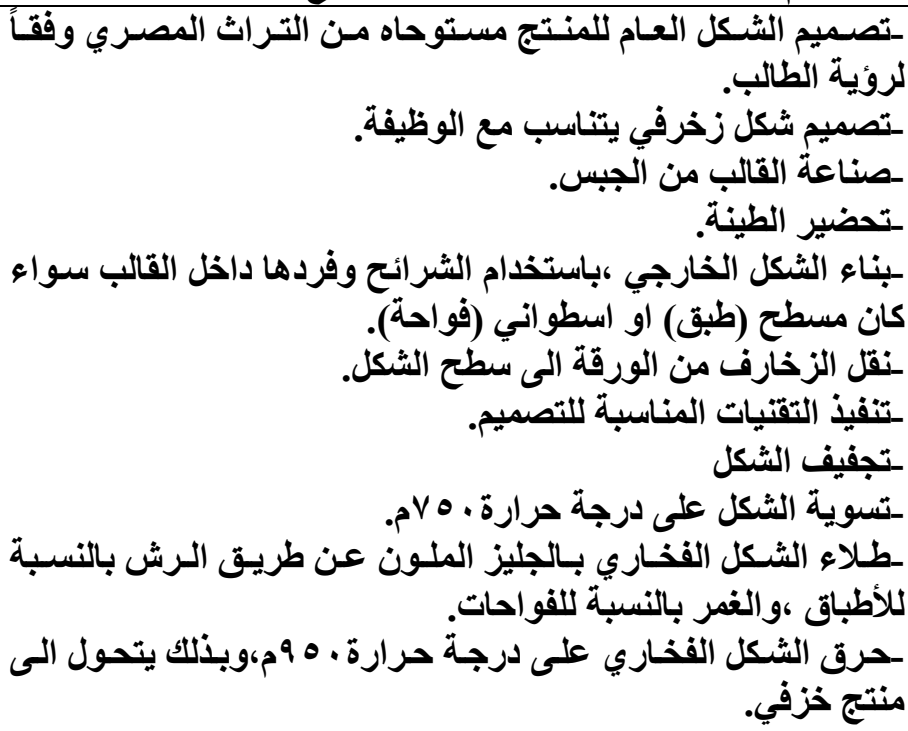 & 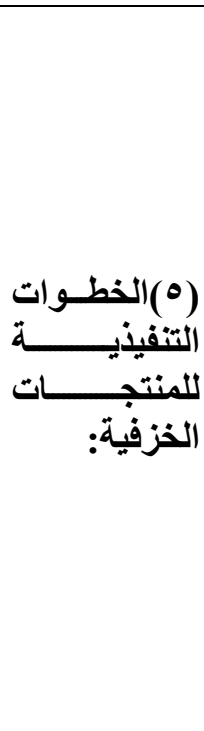 \\
\hline
\end{tabular}




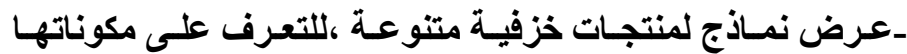

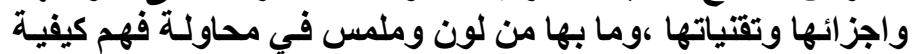

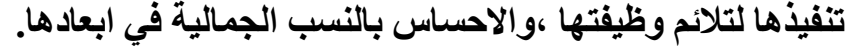

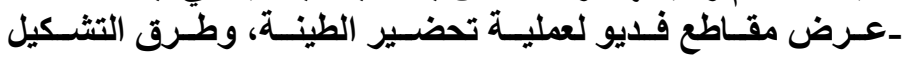
والتلوين. ـعرض رسوم وزخارف من التراث المصري القديم.

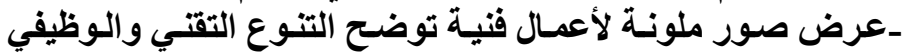

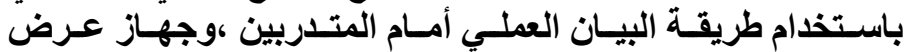

ـعرض عدد كبير من التقتيات المنفذة مـع الشرح باستخدام طريقة البيان العملي امام المتدربين.

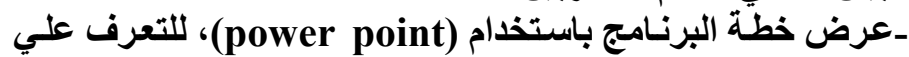

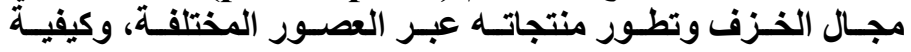
الاستفادة من اقامة مشروعات الصغيرة.

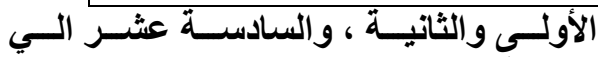

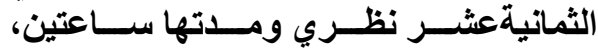

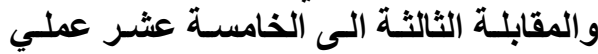

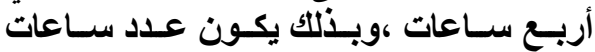

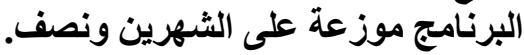
جدول رقم (Y) يوضح توضيح المقابلات في

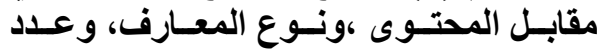

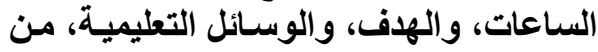
انتاج الباحثة
جدول(1) يوضح الخامات ،الادوات، الاجهزة

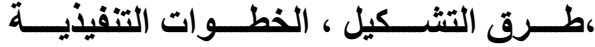

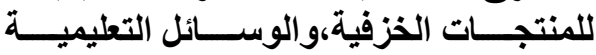

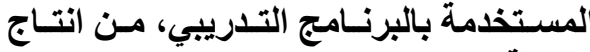

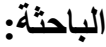
ج-المحتوى العلمـى للبرنـامج المـراد تطبيقهـه والاطار الزمني:

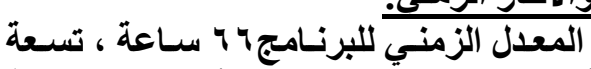

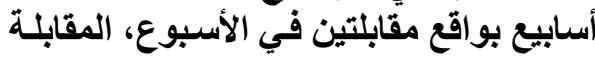

\begin{tabular}{|c|c|c|c|c|c|}
\hline الساعات & التعليمية الوسية & الهدف & المعارف & المحتوي & المقابلة \\
\hline ساعتين & والمحاضريقة & 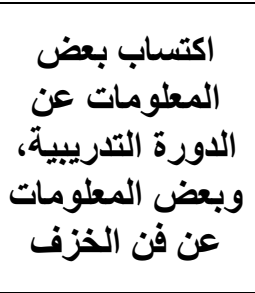 & نظري & 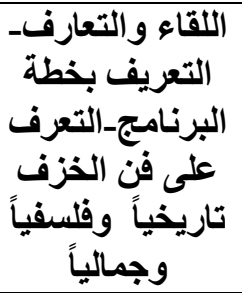 & الأولى \\
\hline
\end{tabular}


الجمعية المصرية للكمبيوتر التعليمى

\begin{tabular}{|c|c|c|c|c|c|}
\hline ساعتين & والمراضثة & 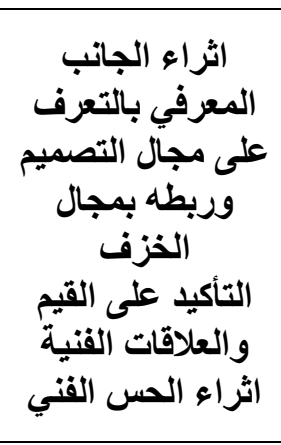 & نظري & 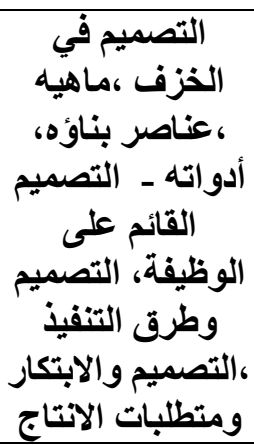 & الثانية \\
\hline ساعاث & كتب ومرضائح & 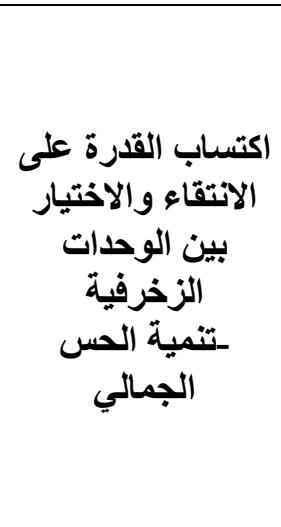 & نظري & 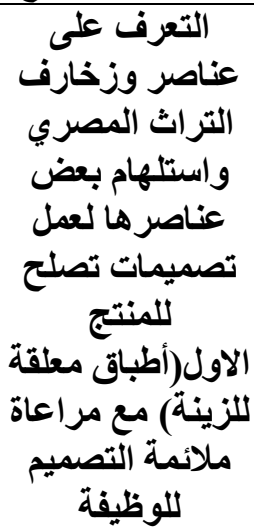 & الثالثة \\
\hline ساعات & البيان العملي & 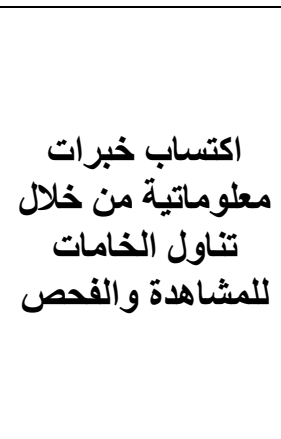 & نظري & 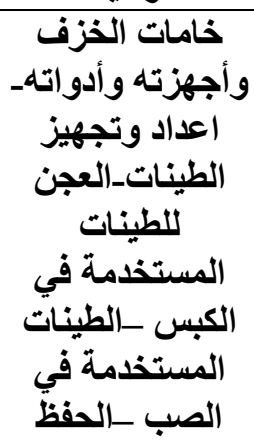 & الرابعة \\
\hline ساعات & عرض العملي - عديان & معلوماتية و ومتساب خبرات & كملي & 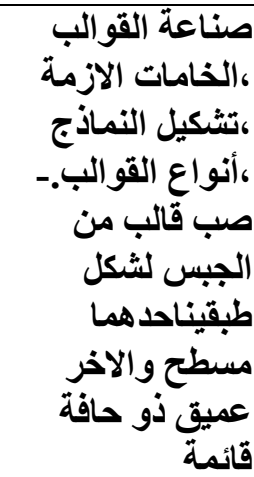 & الخامسة \\
\hline
\end{tabular}


الجمعية المصرية للكمبيوتر التعليمى

\begin{tabular}{|c|c|c|c|c|c|}
\hline ساعات & 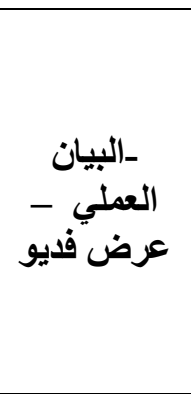 & 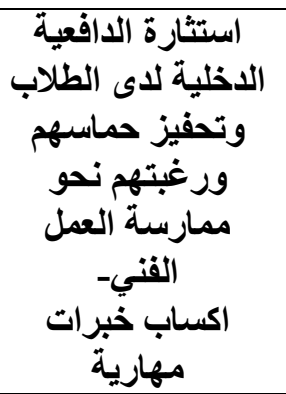 & عملي & 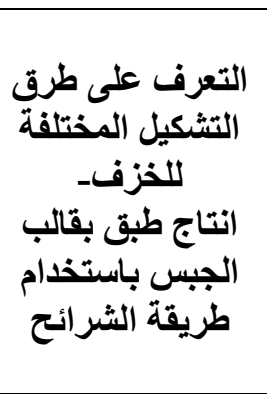 & السادسة \\
\hline ساعات & بصرية تلتمثل & 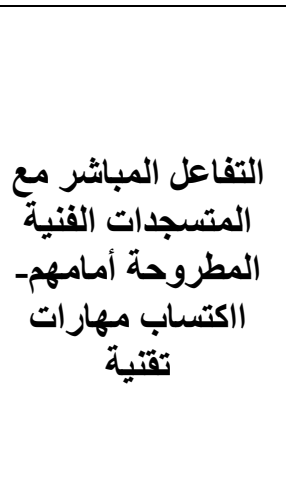 & يي & 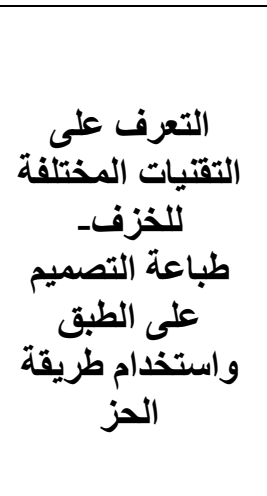 & السابعة \\
\hline ساعات & خلا ممارسة التدريب من الخامة & 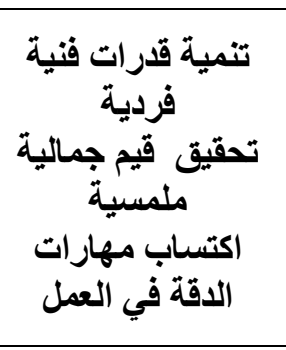 & & 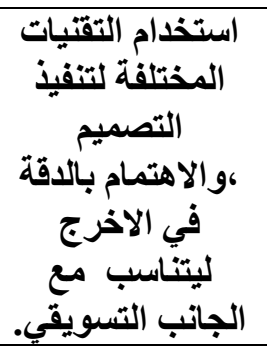 & والتاسعة الثامنة \\
\hline ساربات & 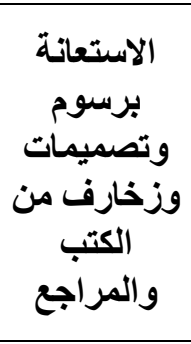 & تالانتقاء والاخت القدرة على التيار & ي & 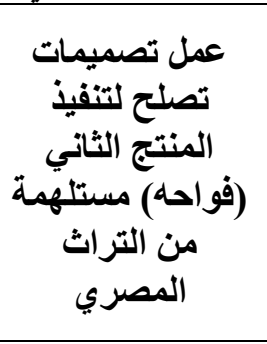 & العاشرة \\
\hline ساربع & البيان التماريب & اكتساب مهار ات & 1 & لبناعة قالب لشكل & عشري \\
\hline ساربع & التجريب & في العلاقات قيم الشكلية & ملى & تشكيل الثكل & عثر \\
\hline
\end{tabular}

(Y^०)

سلسلة دراسات ويحوث مُحكُمَة .. عدد خاص بالبحوث المحكمة في المؤتمر العلمي الثالث ه 1 ـ ب 
الجمعية المصرية للكمبيوتر التعليمى

\begin{tabular}{|c|c|c|c|c|c|}
\hline & خلالتل الخامة من & تنمية القدرة & & 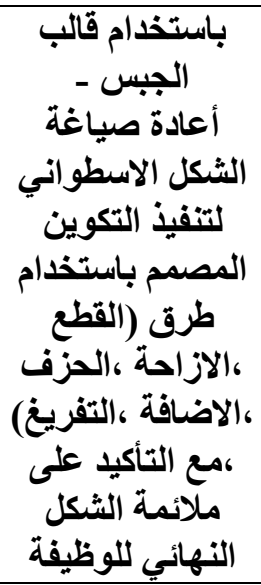 & \\
\hline ساعات & & تحقيق علاقة تبادلية & & 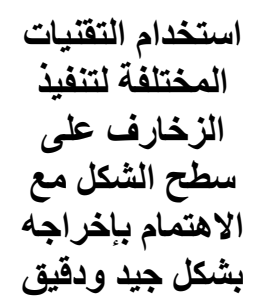 & عشر \\
\hline ساعات & شرائح & 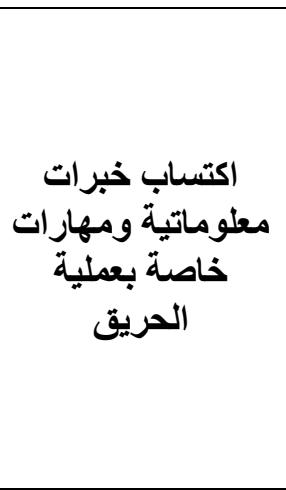 & لي & 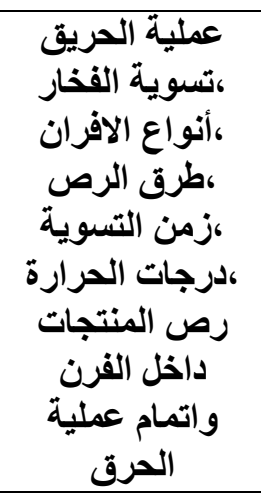 & عثر الر ابعة \\
\hline ساعات & البيان العملي & 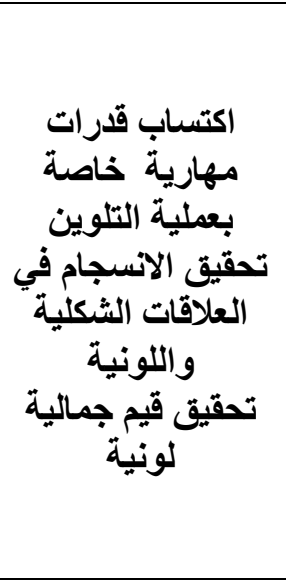 & عملي & 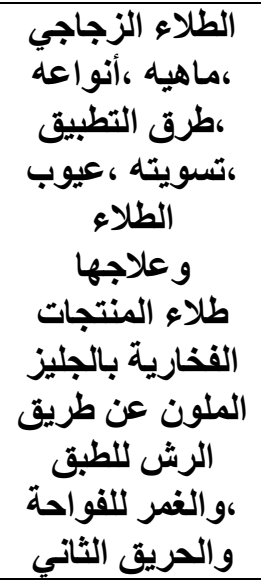 & الخامسة \\
\hline
\end{tabular}

$-(Y \wedge \eta)$

سلسلة دراسات ويحوث مُحكُمَة .. عدد خاص بالبحوث المحكمة في المؤتمر العلمي الثالث ه 1 ـ ب 


\begin{tabular}{|c|c|c|c|c|c|}
\hline ساعتين & والمحاضرة & 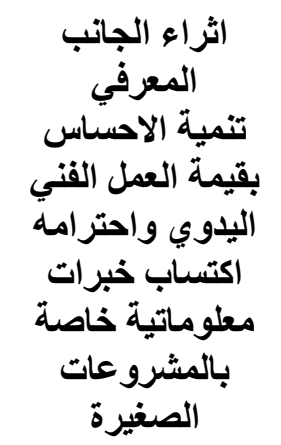 & نظري & 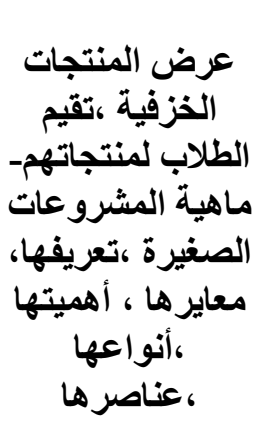 & عشادسة \\
\hline ساعتين & والمحاضرة & 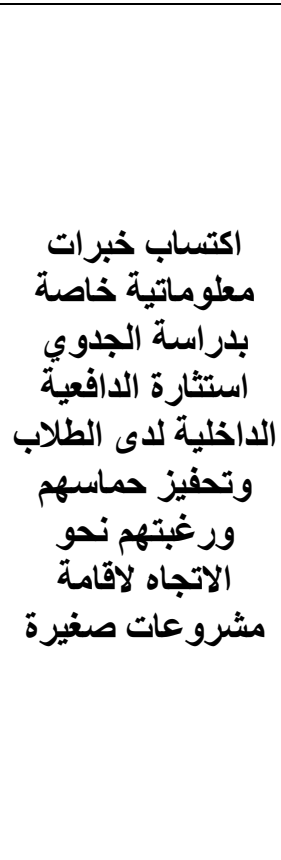 & نظري & 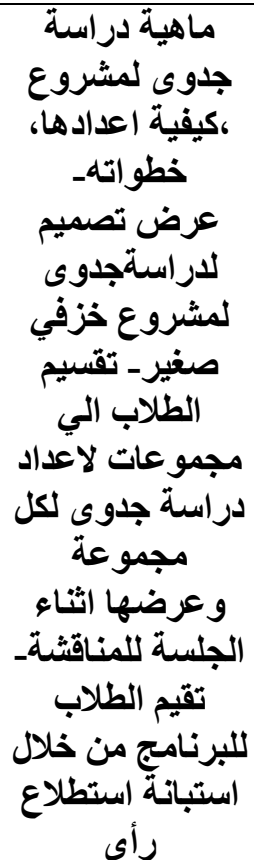 & والثامنة عشرة \\
\hline
\end{tabular}

r بـيـاس أثر البرنـامج التدريبي على تنميـة

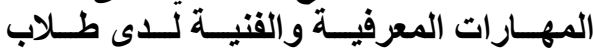
و الجامعة فئه

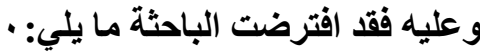

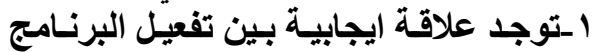

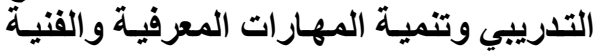

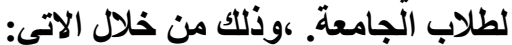

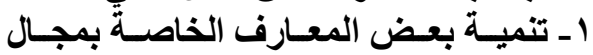

ثانياً _النتائج التي توصلت اليها الباحثة من خلال البرنامج التدريبي: التياني: تحليل النتائج في ضون الئو الفروض احصائيا

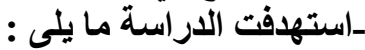

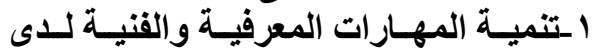

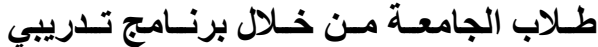
للاتجاه نحو المشروعات الصغيرة.

$$
\text { الخزف لأى طلاب الجامعة. }
$$


r ـ تتميـة بعض المهـار ات الخاصـة بالتشكيل

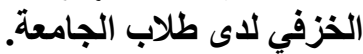

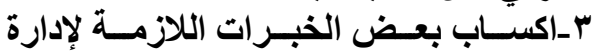
المشروعات الصغيرة لاى طلاب الجامعة.

ونتائج الفرض الاول:

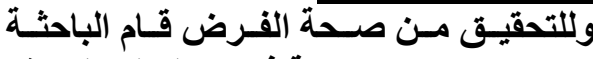

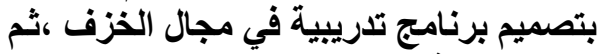

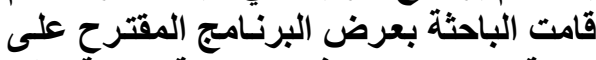

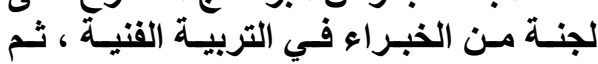

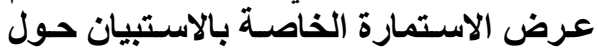

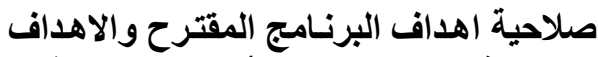

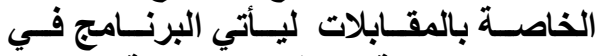

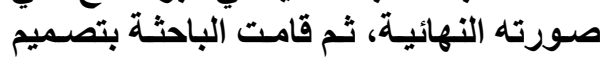

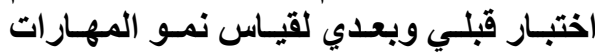

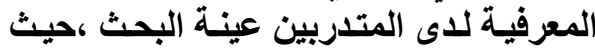

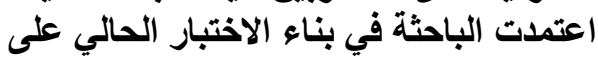

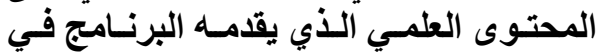

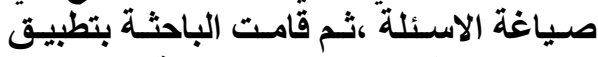

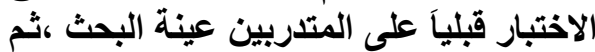
قامـت بتطبيقها مـرة اخـرى على الإنى المتـدربين

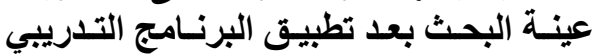

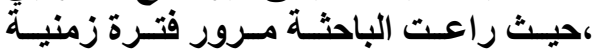
مناسبة وهى فترة تطبيق البرنـامج ومـدتها

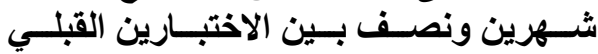

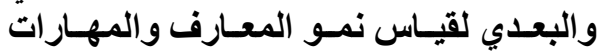
القنية كما يلي

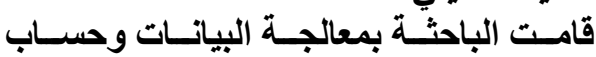

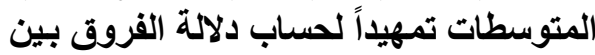

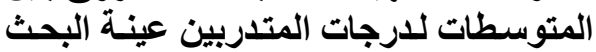

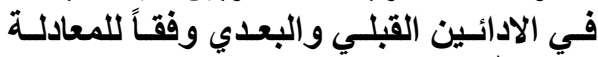
التالية الفي الجانب ألمعرفي. 


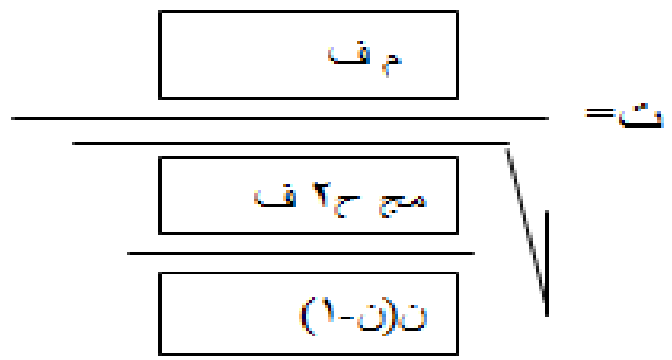

حيث م ف= متوسط الفروق بين درجات القبلي والبعدي .

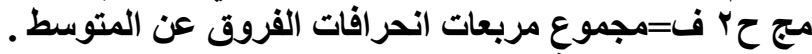

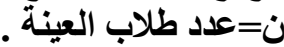

\begin{tabular}{|c|c|c|c|c|}
\hline حז'ف & حف & ف & بعدي & قبلي \\
\hline ,49 & $7,+$ & 11 & 19 & 8 \\
\hline 13,69 & $3,7+$ & 14 & 20 & 6 \\
\hline 13,69 & $3.7+$ & 14 & 20 & 6 \\
\hline 2,89 & $1,7+$ & 12 & 19 & 7 \\
\hline 2,89 & $1,7+$ & 12 & 20 & 8 \\
\hline 1,69 & $1,3-$ & 9 & 18 & 9 \\
\hline 13,69 & $3,7+$ & 14 & 20 & 6 \\
\hline 2,89 & $1,7+$ & 12 & 19 & 7 \\
\hline 2,89 & $1,7+$ & 12 & 19 & 7 \\
\hline 2,89 & $1,7+$ & 12 & 19 & 7 \\
\hline 2,89 & $1,7+$ & 12 & 18 & 6 \\
\hline 13,69 & $3,7+$ & 14 & 20 & 6 \\
\hline 2,89 & $1,7+$ & 12 & 20 & 8 \\
\hline, 49 & $7,+$ & 11 & 19 & 8 \\
\hline 2,89 & $1,7+$ & 12 & 18 & 6 \\
\hline 13,69 & $3,7+$ & 14 & 20 & 6 \\
\hline ,49 & $1,3-$ & 9 & 18 & 9 \\
\hline 47,88 & صفز & 124 & 332 & 104 \\
\hline
\end{tabular}

( $९ \wedge$ १

سلسلة دراسات ويحوث مُحكُمَة .. عدد خاص بالبحوث المحكمة في المؤتمر العلمي الثالث ه 1 ـ ب 
جدول(ץ)يوضح عمليات حساب قيمة ت لارجات الطلاب في الجاتب المعرفيوبالتعويض في المعادلة نجد أن:

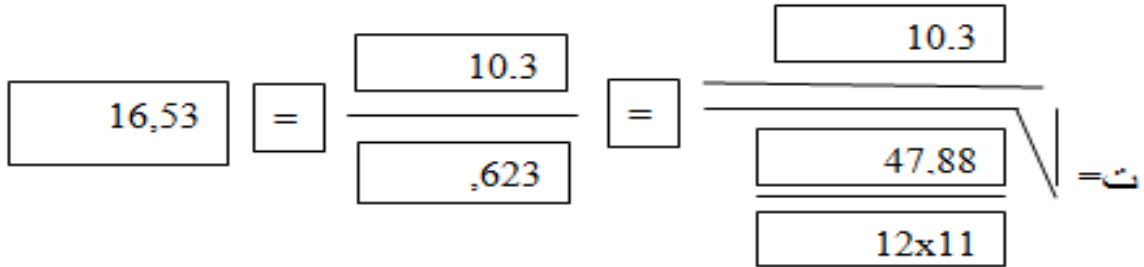

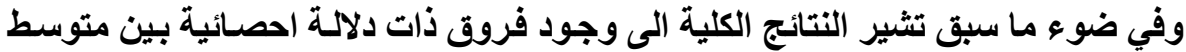

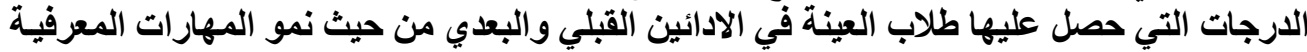

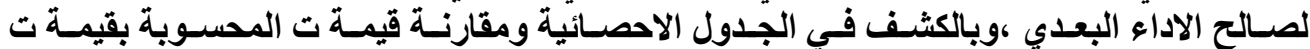

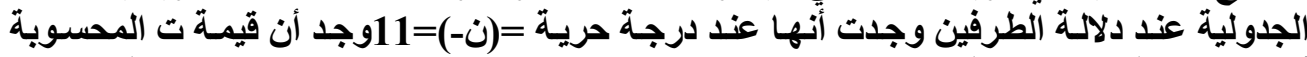

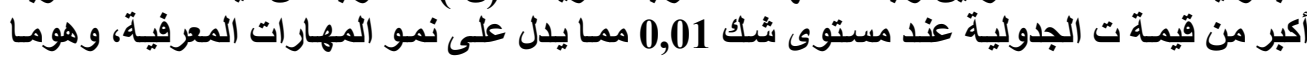

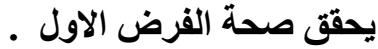

تلتتائج الفرض من صحة الثانى:

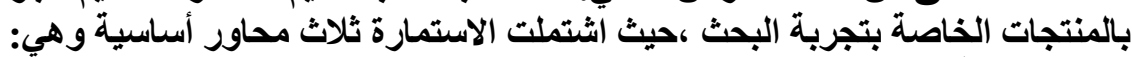
أولاً: العناصر التصاصة التصريمية البحيث ا الاستلهام من المفردات الترية التراثية أو الهندسية في بناء المنتج الخزفي.

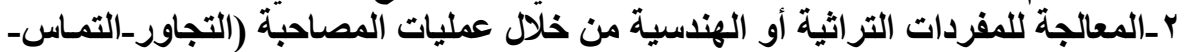

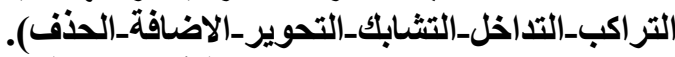

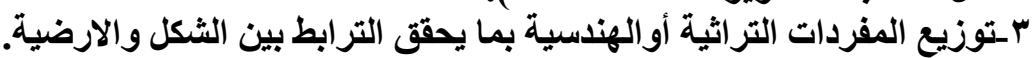

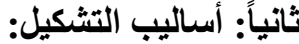
ا ـتتوع التقتيات بما يحقق الثراء التشيل التثكيلي

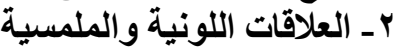

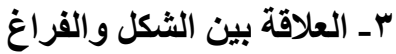
ع ـالتأكيد على جودة الإخراج ثالثاً: الجوانب الوظيفية علئة ا ـملائمة الشكل والوظيفة الوظيفة في المنتج الخزفي.

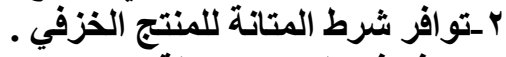
ب-يتوفر في المنتج سهولة الاستخدأم.

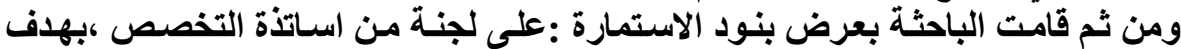

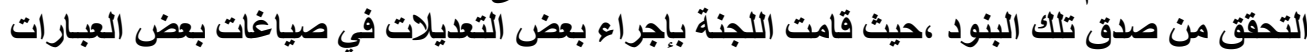

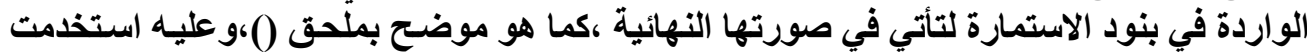

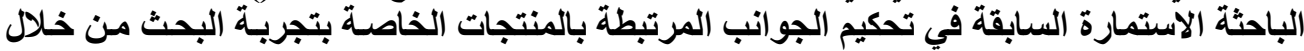

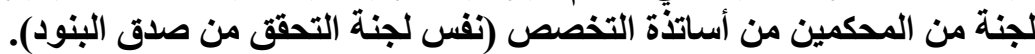

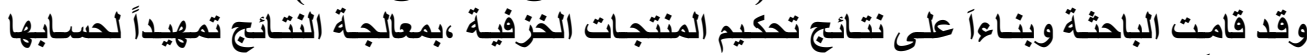

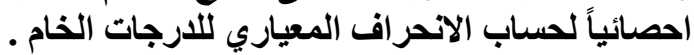


ويوضح الجدول التالي عمليات حساب الانحراف المعياري لبنود استمارة تحكيم الجوانب المرتبطة بالمنتجات الخاصة بتجربة البحث.

\begin{tabular}{|c|c|c|c|}
\hline ح' عن المنتوسط الانحراف) & $\begin{array}{c}\text { ح (الانحراف) } \\
\text { المعيارى) }\end{array}$ & ק ( متوسط) & دمكم وعلد اعمال) عثرة \\
\hline 170.38 & 41.26- & 778.26 & 737 \\
\hline 769.5 & 27.74+ & 778.26 & 806 \\
\hline 120.86 & 34.74+ & 778.26 & 813 \\
\hline 175.82 & 13.26- & 778.26 & 765 \\
\hline 1007.42 & 31.74+ & 778.26 & 810 \\
\hline 104.85 & 10.24- & 778.26 & 768 \\
\hline 68.22 & 8.26- & 778.26 & 770 \\
\hline 769.5 & $27.74+$ & 778.26 & 806 \\
\hline 232.86 & 15.26- & 778.26 & 763 \\
\hline 884.46 & $29.74+$ & 778.26 & 808 \\
\hline 824.98 & 28.74+ & 778.26 & 807 \\
\hline 232.86 & 15.26- & 778.26 & 763 \\
\hline 333.42 & 18.26- & 778.26 & 760 \\
\hline 85.74 & 9.26- & 778.26 & 769 \\
\hline 1040.7 & 32.26- & 778.26 & 746 \\
\hline 297.9 & 17.26- & 778.26 & 761 \\
\hline 370.94 & 19.26- & 778.26 & 759 \\
\hline 7490.41 & صفر & ............ & 13211 \\
\hline
\end{tabular}

وقد استخدمت الباحثة المعادلة التالية:

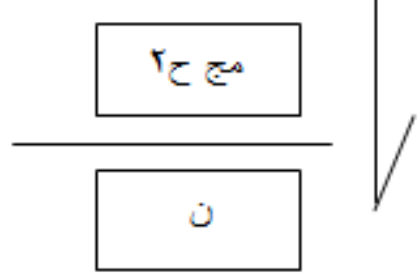

الانحراف المعياري =

حيث مج حr = مجموع مربع الانحراف عن المتوسط

ن=عداد اعمال التجربة فكانت نتيجة الانحراف المعياري كما يلي: 


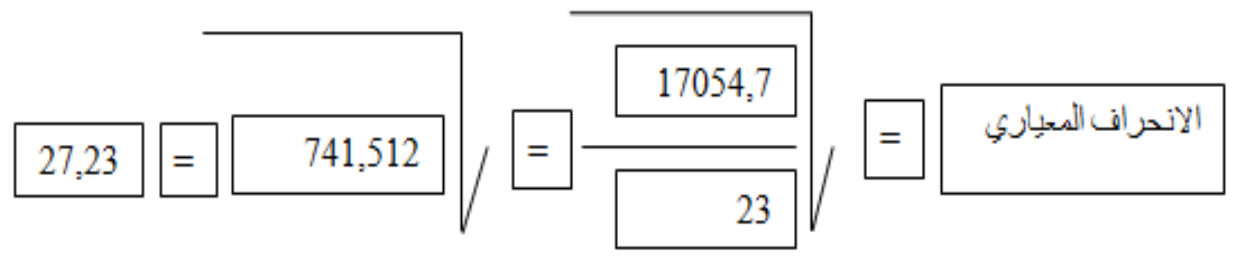

وبذلكتتمثل نتائج تطبيث البرنامج التدريبي

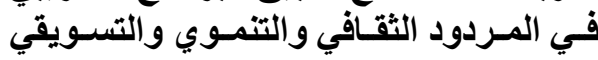
كالثالي: - المي الميز ا ـالمردود الثقافي يتمثل في كم المعلومسات

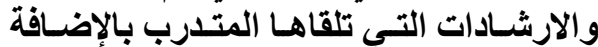

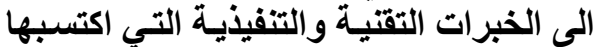
خلال فترة التخبرات التدريب.

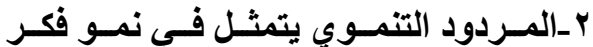

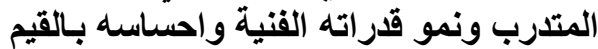

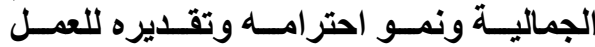

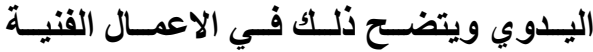

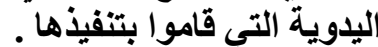

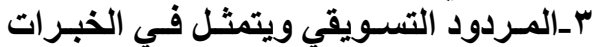

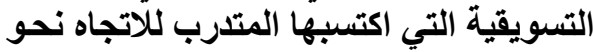
المشروعات الصغيرة.

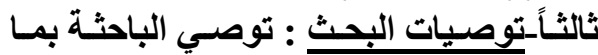
يلي :

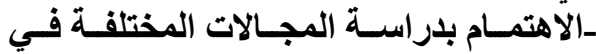

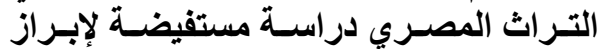

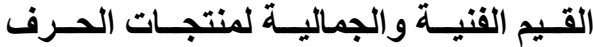

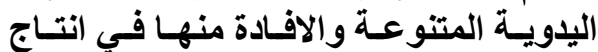

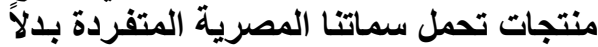

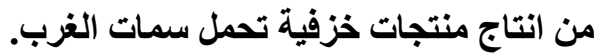

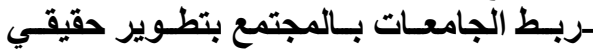

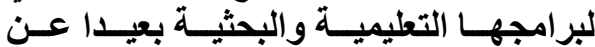

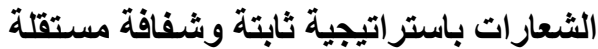

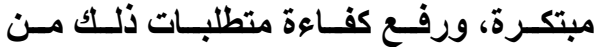

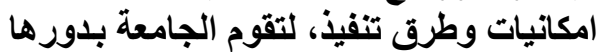

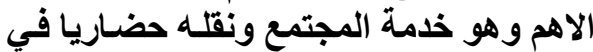

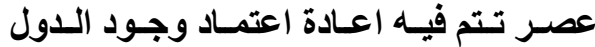

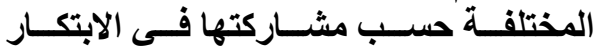

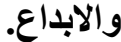

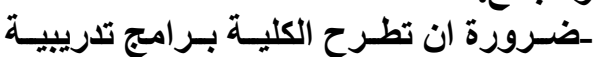

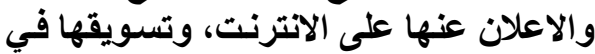

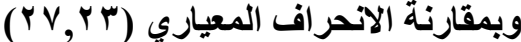

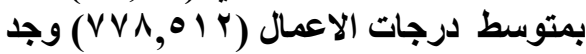
ان نسبة التشتت عن المتوسط تمثئل نسبة

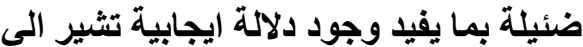

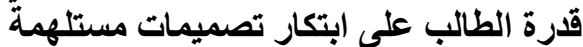

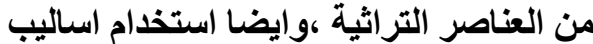

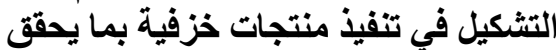
محددات التصميم بمهارة ،وايضا مراعاة الجوانب الوظيفية (الاستخدامية والجمالية ) للمنتجات، بما يحقق استحداث منتجات ترقى المئه

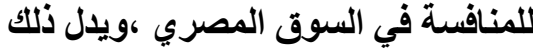

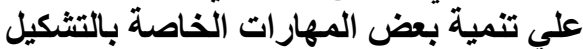

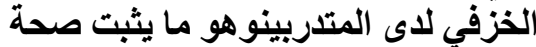
الفرض الثاني.

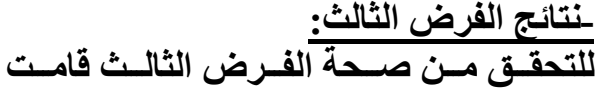

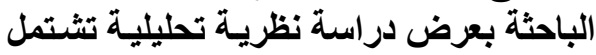

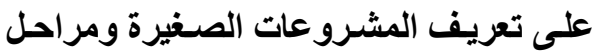

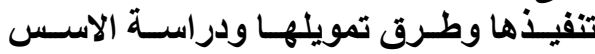

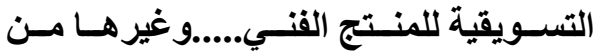

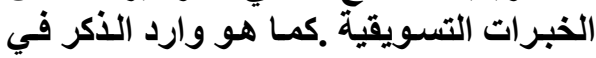

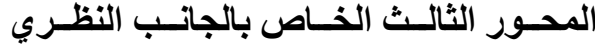
للبرنـامج التدريبي.

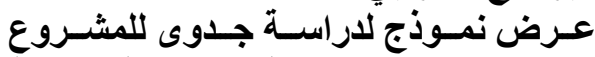

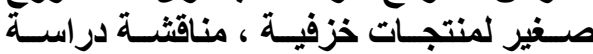

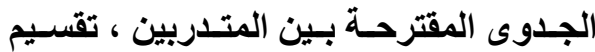

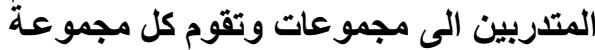

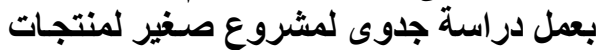

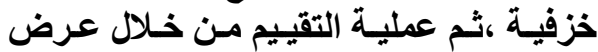

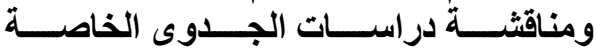
بالمتدربين لتوضيح نقاط الضعف والقوة التور بكل

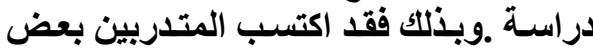
الخبرات اللازمة لإدارة المشروعات التهات الصغيرة وهو ما يحقق الفرض الثالث. 
الجماعي، فن التسويق، فن التظليف، القانون التجاري - التماعي ـضرورة الاهتمـام بتــاول الحاسـب الالـي في

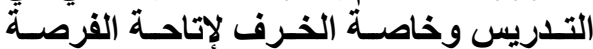

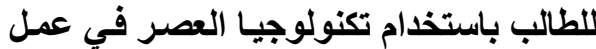
تصسميمات متعـددة بحلـول مختلفــة لاختيـار

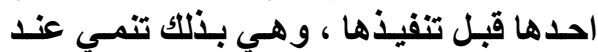

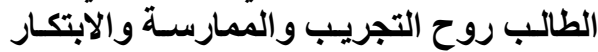
في اقل وقت.

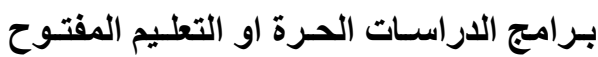

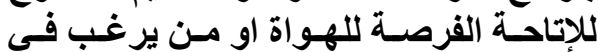

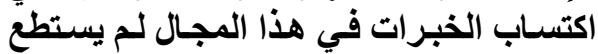

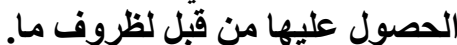

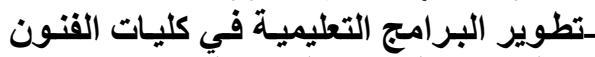

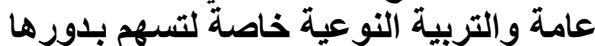

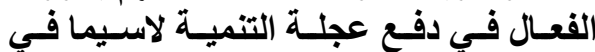

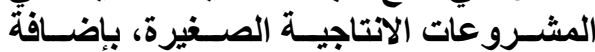

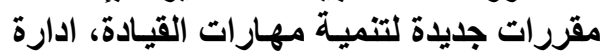
المشروعات الاتتاجيـة، المشـاركة في العمل لفيل

صور لمعلقات فنية مستوحاه من التراث المصري على شكل أطباق خزفية ،من انتاج الطلاب
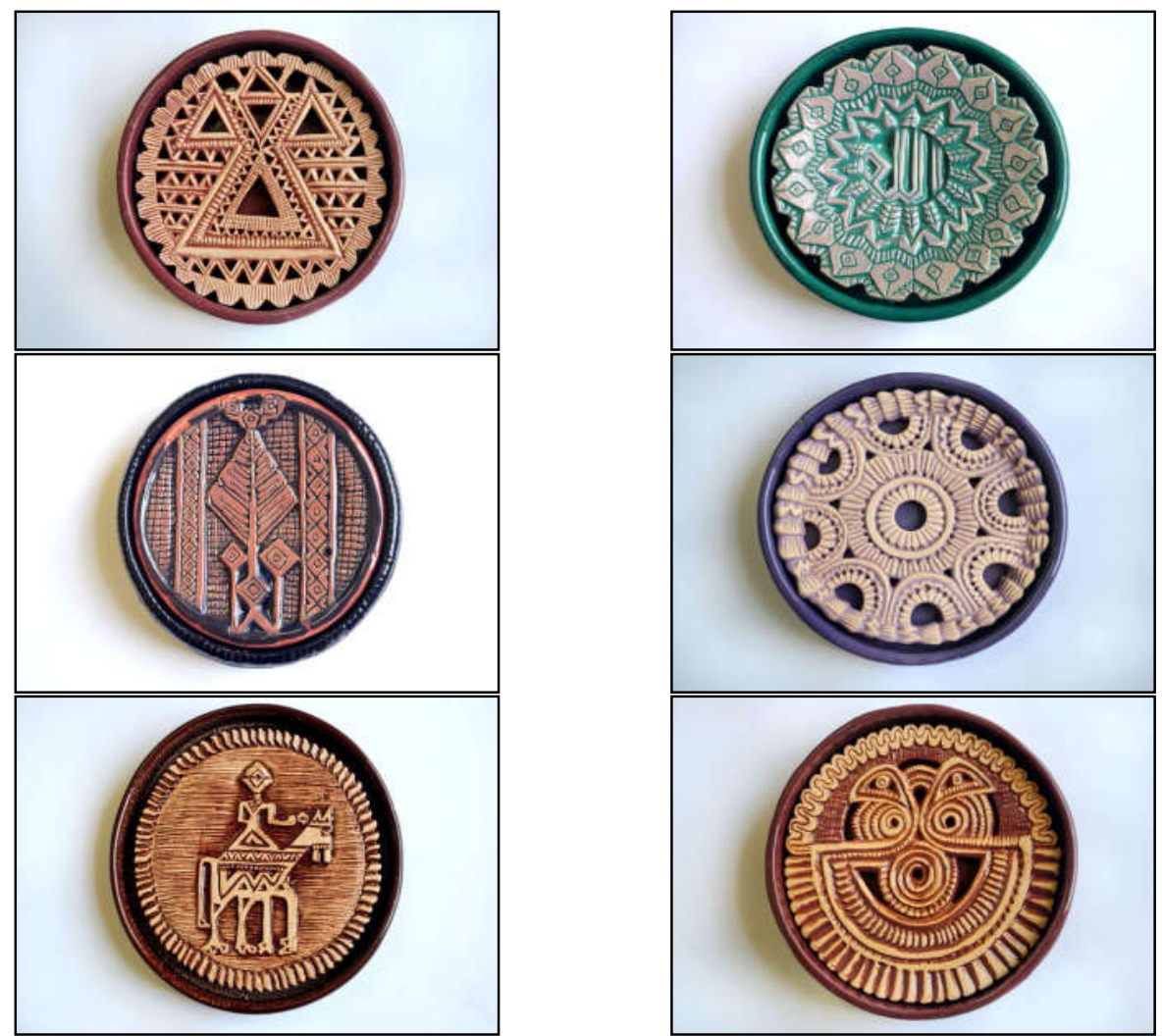


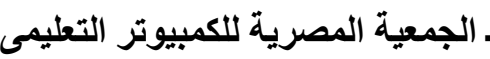
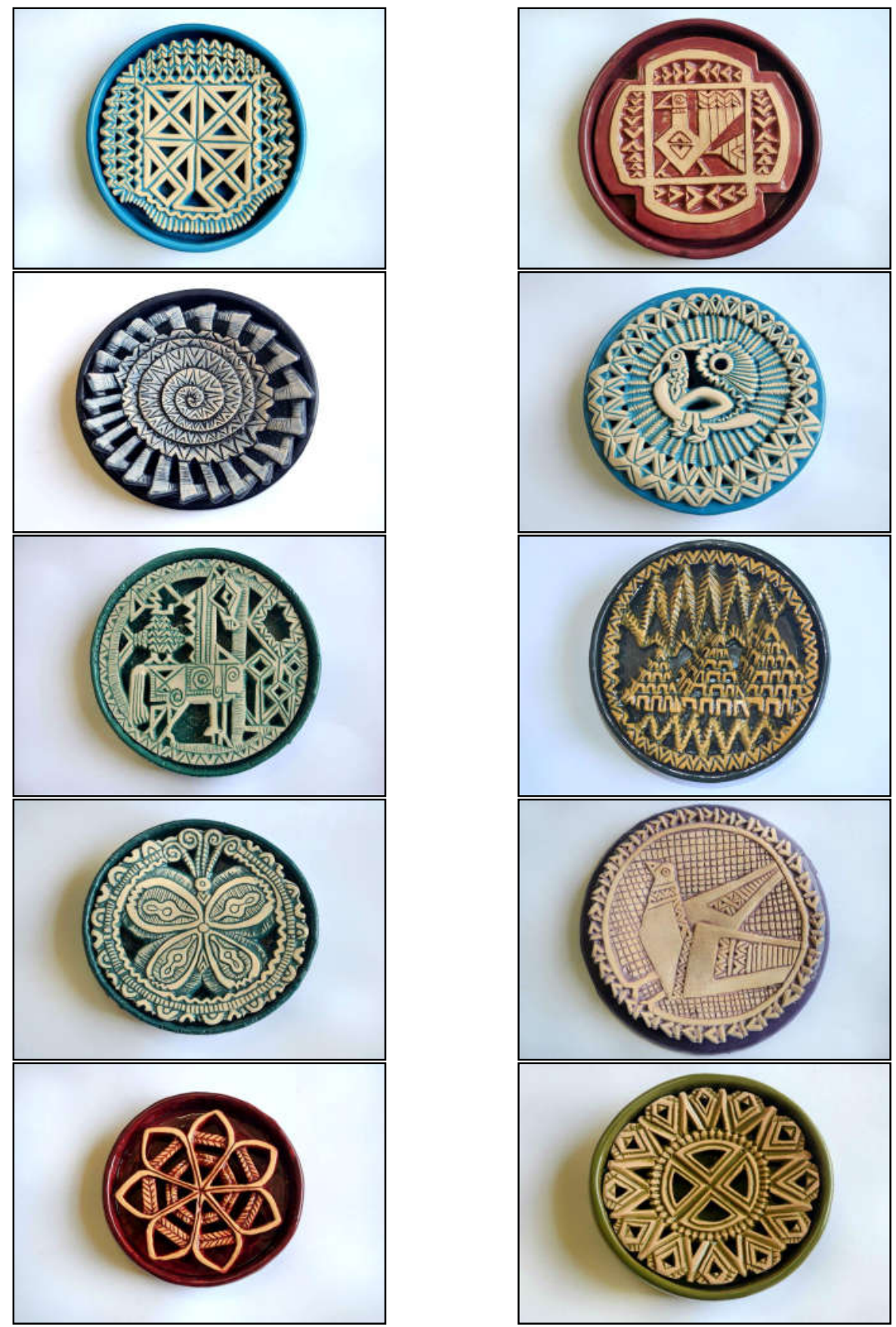

(Yq $($ Y $)$

سلسلة دراسات ويحوث مُحكُمَة .. عدد خاص بالبحوث المحكمة في المؤتمر العلمي الثالث ه 1 ـ ب 


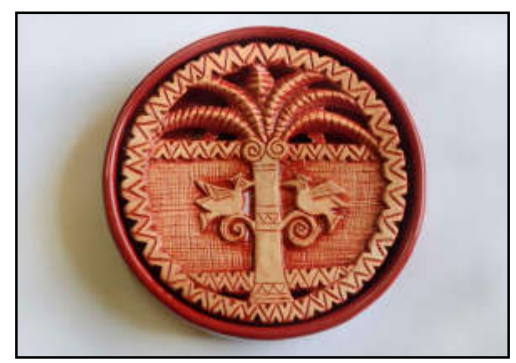

(rqo)

سلسلة دراسات وبحوث مُحكُمَة .. عدد خاص بالبحوث المحكمة في المؤتمر العلمي الثالث ه 1 ـ ب 
صور لفواحات مستوحاه من التراث المصري على شكل أسطوانات خزفية ،من انتاج الطلاب
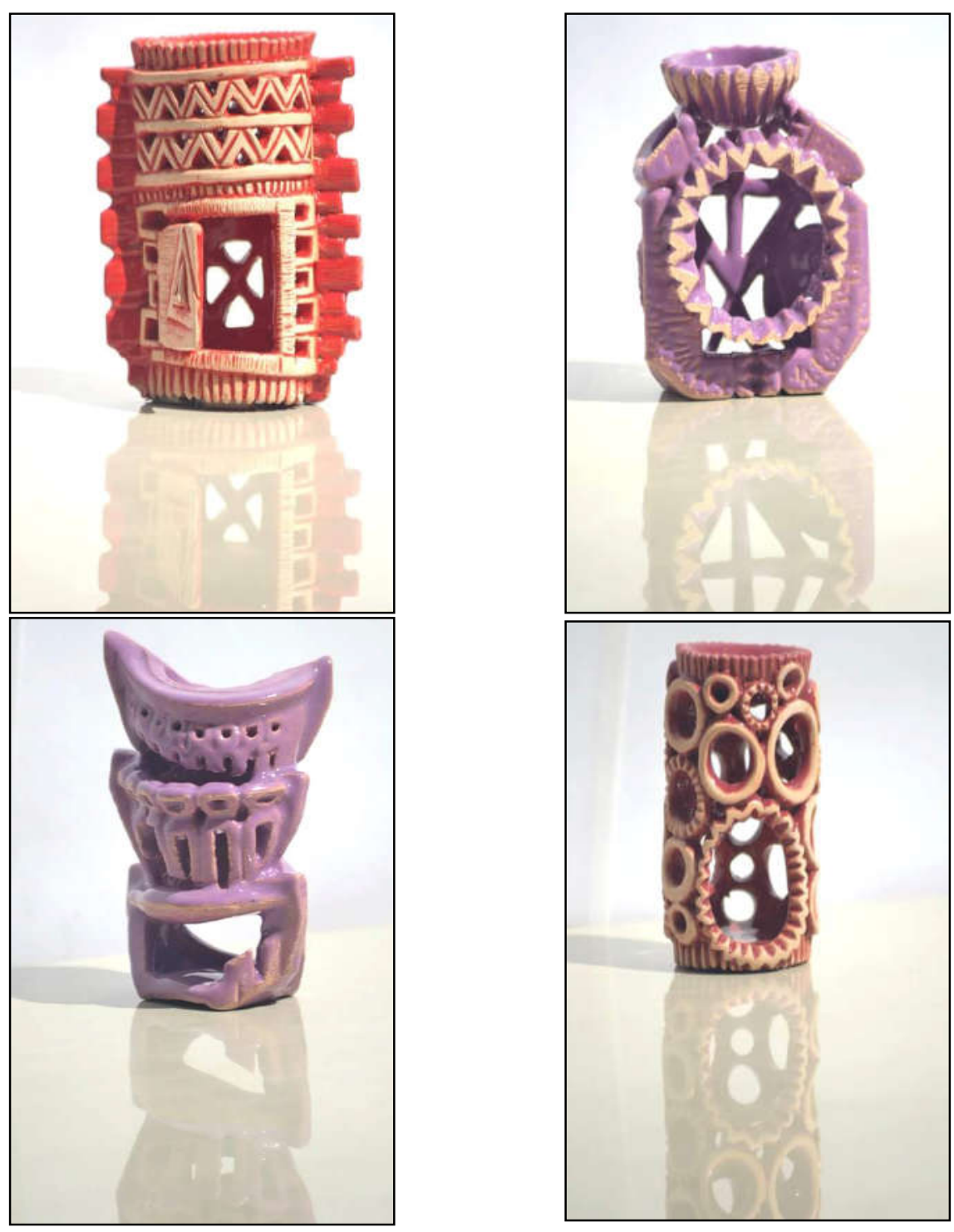

$($ ( 9 ४ $)$

سلسلة دراسات ويحوث مُحمُمَة .. عدد خاص بالبحوث المحكمة في المؤتمر العلمي الثالث ه 1 ـ ب 
الجمعية المصرية للكمبيوتر التعليمى - التمى
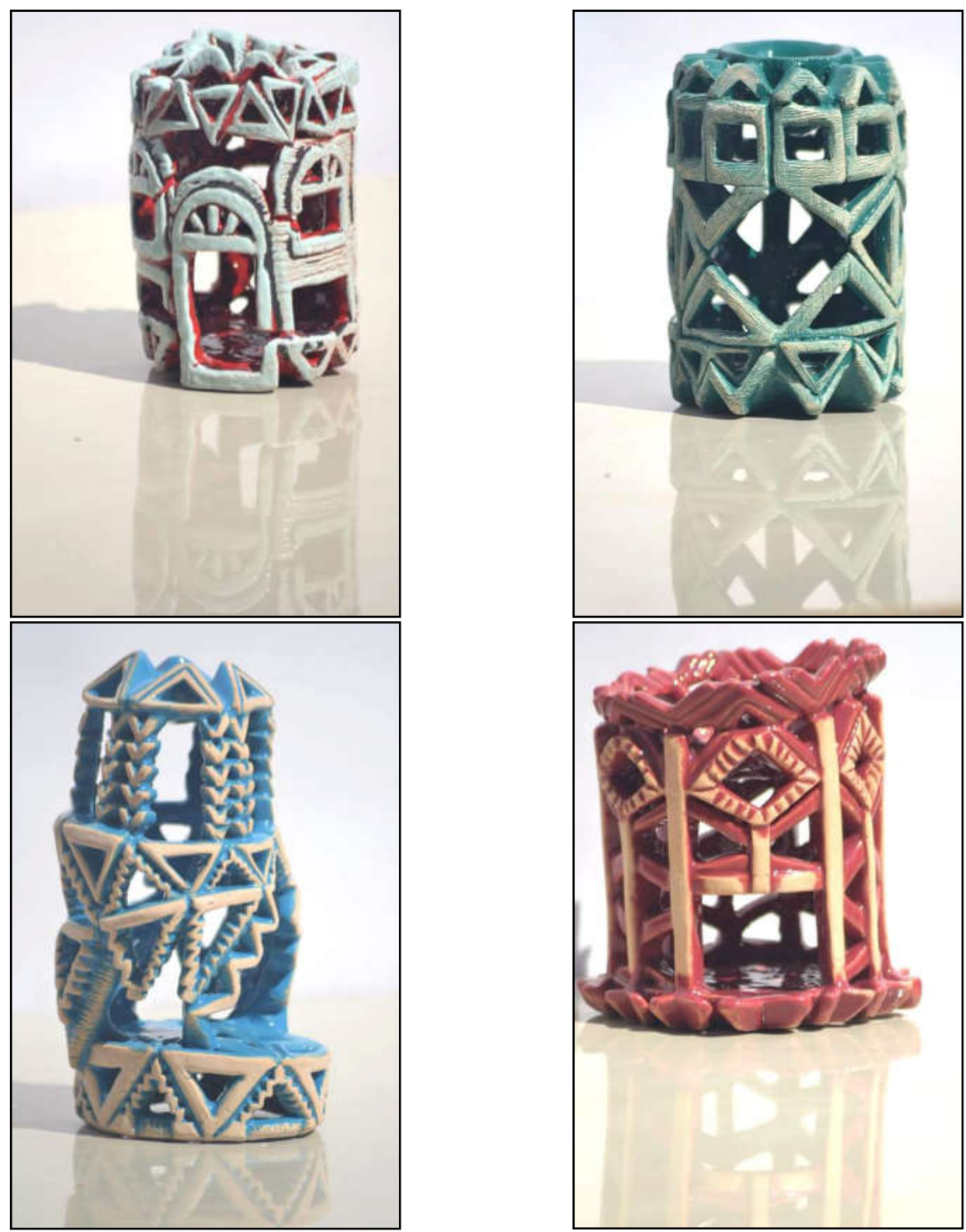

(rqv)

سلسلة دراسات ويحوث مُحمُمَة .. عدد خاص بالبحوث المحكمة في المؤتمر العلمي الثالث ه 1 ـ ب 


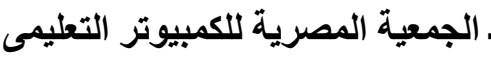
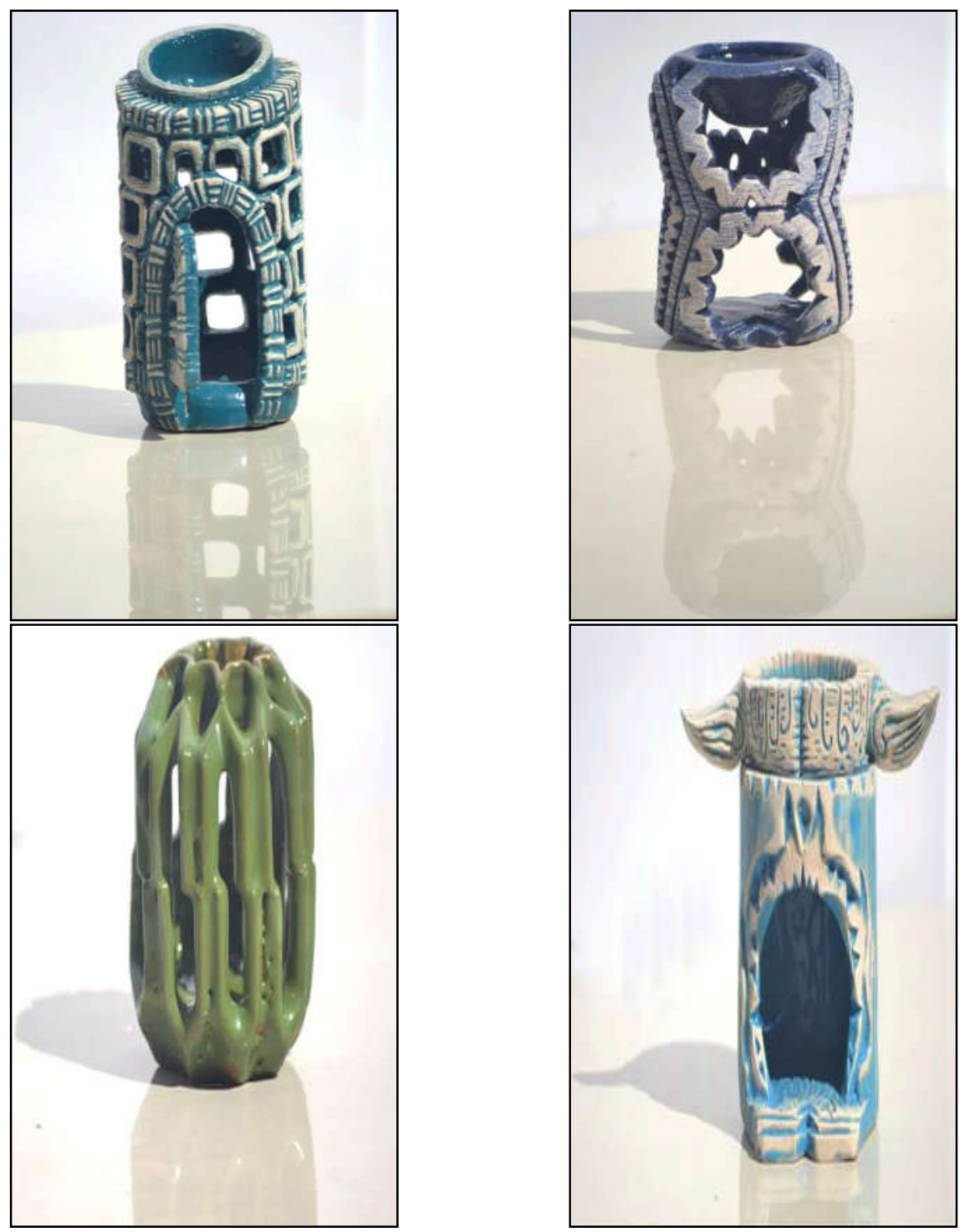

$(r q \wedge)$

سلسلة دراسات ويحوث مُحمُمَة .. عدد خاص بالبحوث المحكمة في المؤتمر العلمي الثالث ه 1 ـ ب 


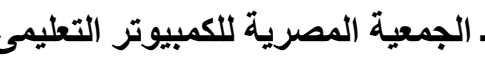
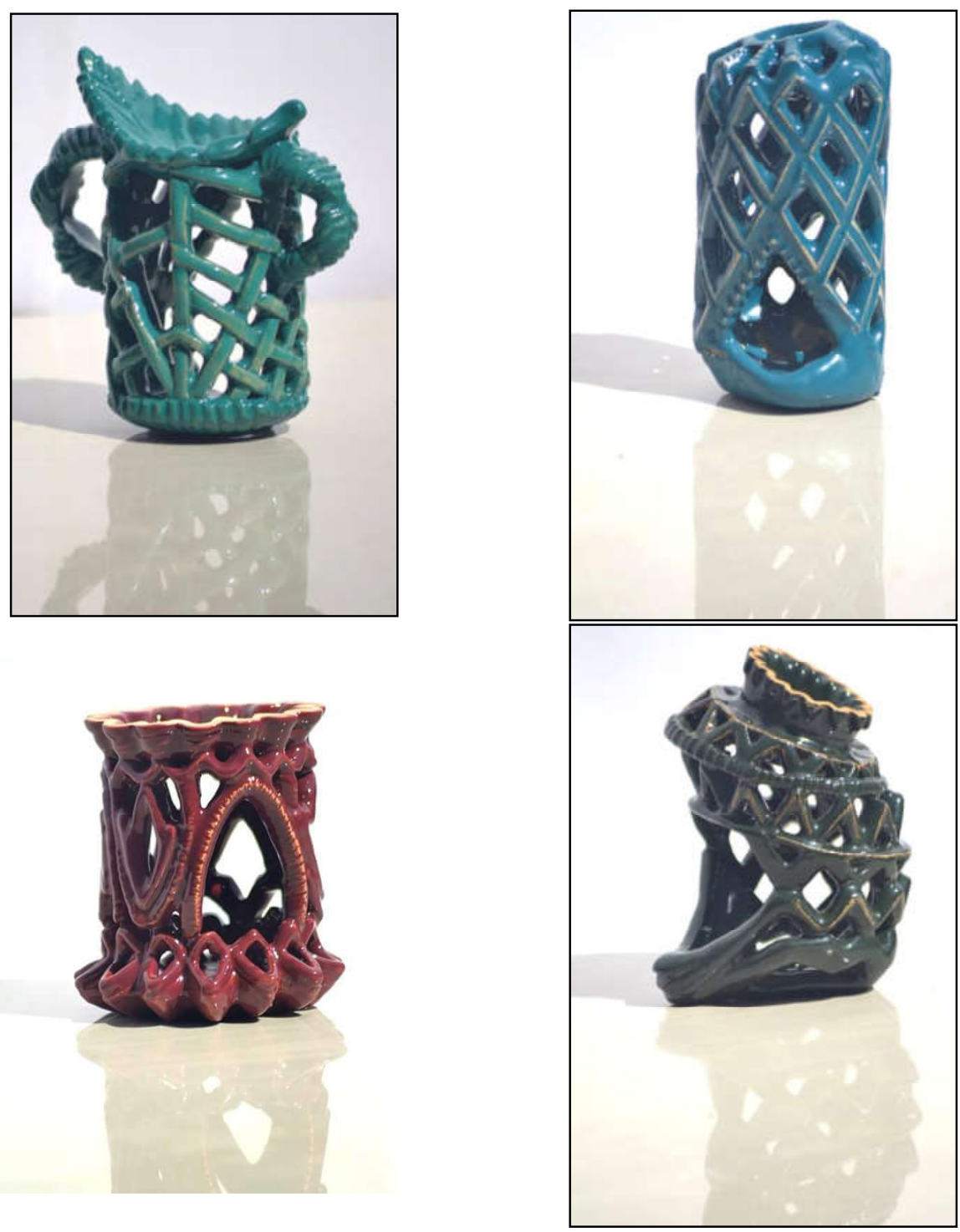

(r9q)

سلسلة دراسات ويحوث مُحمُمَة .. عدد خاص بالبحوث المحكمة في المؤتمر العلمي الثالث ه 1 ـ ب 
الجمعية المصرية للكمبيوتر التعليمى

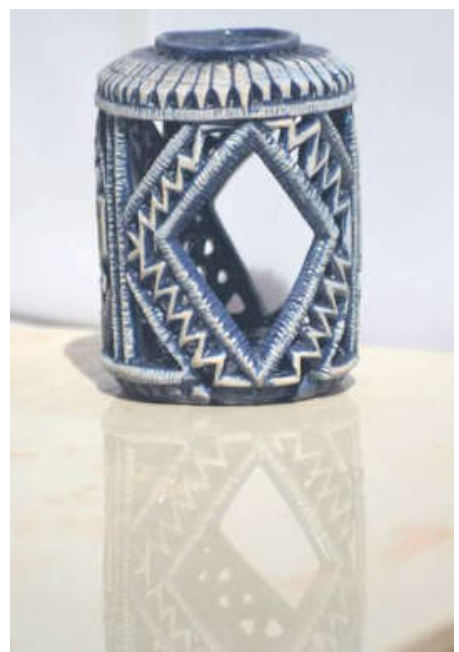

$(r \cdot \cdot)$

سلسلة دراسات ويحوث مُحكُمَة .. عدد خاص بالبحوث المحكة في المؤتمر العلمي الثالث ه 1 . ب 


\section{استمارة تحكيم المنتجات الخزفية}

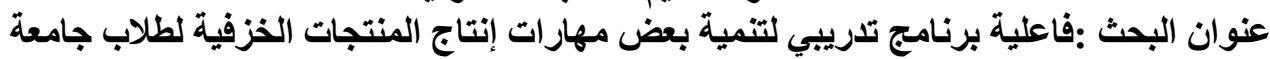

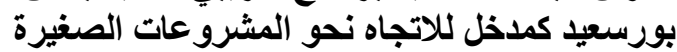

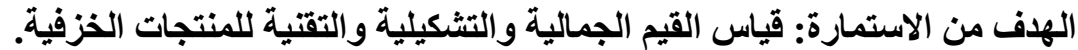

\begin{tabular}{|c|c|c|c|c|c|c|}
\hline 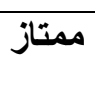 & جياجداً & جيد & مقبول & ضعيف & عوامل تقيم المنتجات الخزفية & الاستمارة \\
\hline & & & & & 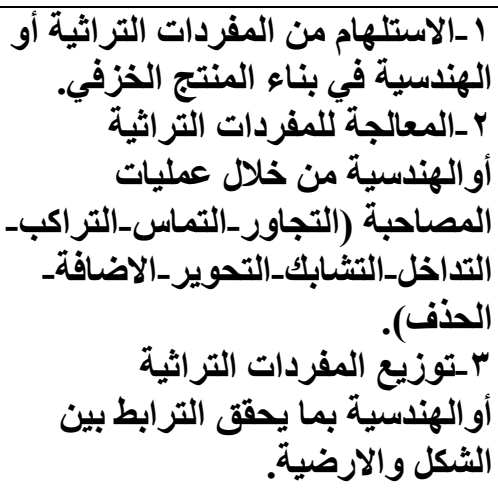 & أولاً:العناصية \\
\hline & & & & & 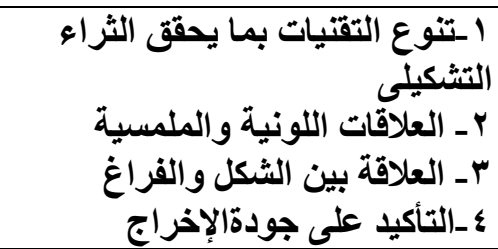 & ثُانياً:أساليب \\
\hline & & & & & 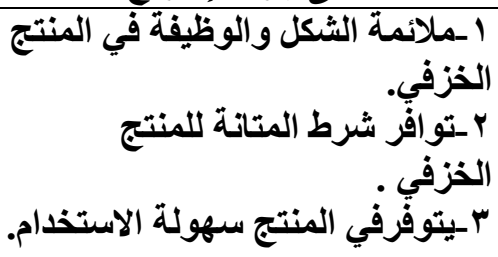 & ثالثاً:الجوانب \\
\hline
\end{tabular}

ملحق( ) استمارة تحكيم المنتجات الخزفية 


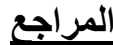

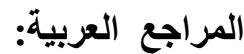

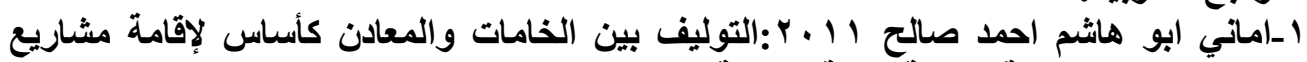

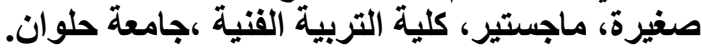

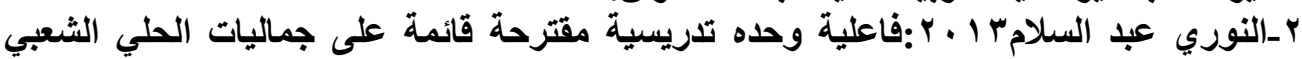

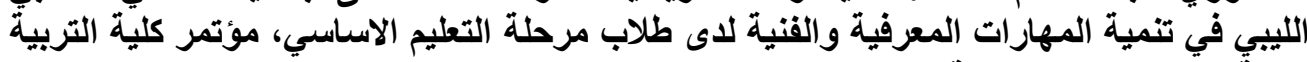

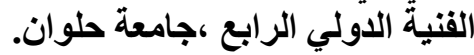

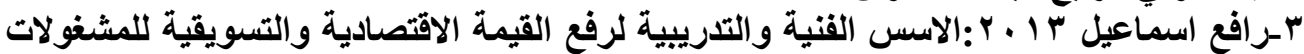

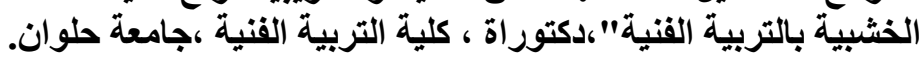

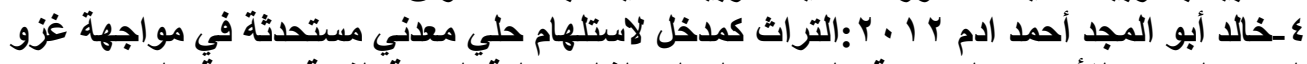

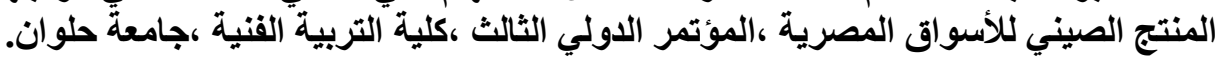

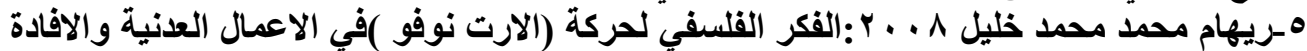

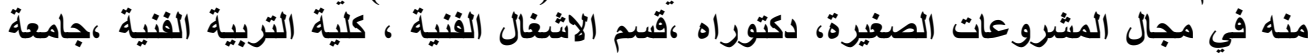
حلوان

צ-عبد العزيز عطا عبد العزيز •99 19 1: تصميم برنامج لتنمية الفخار الشعبي المصري كصناعة

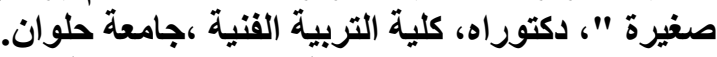

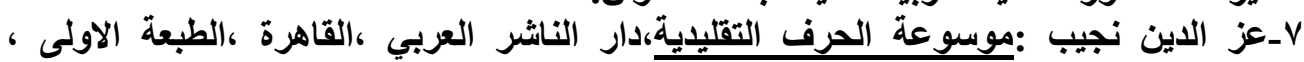
r...

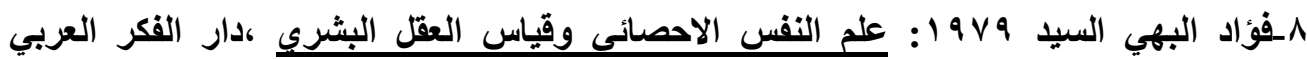

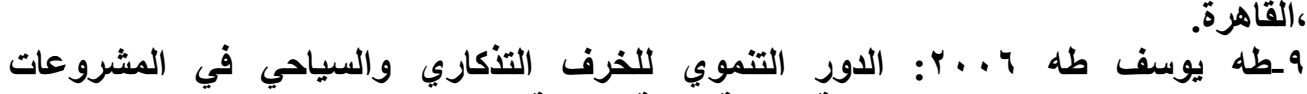

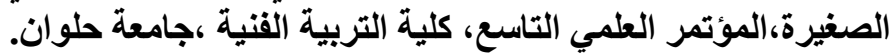

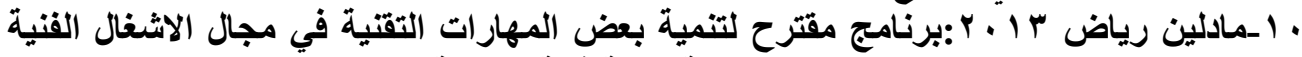

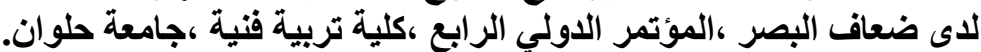

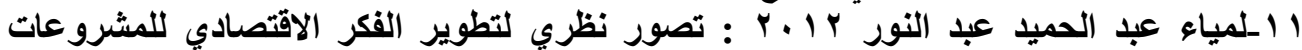

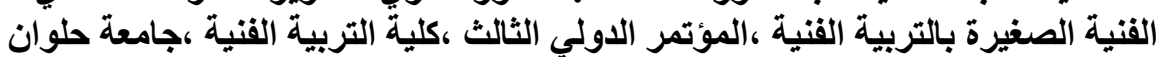

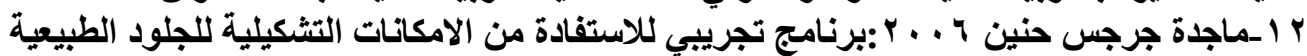

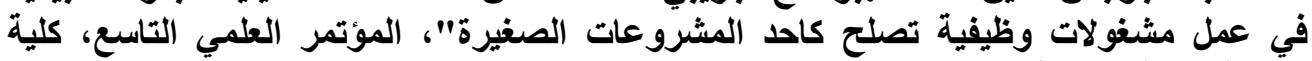

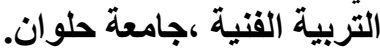

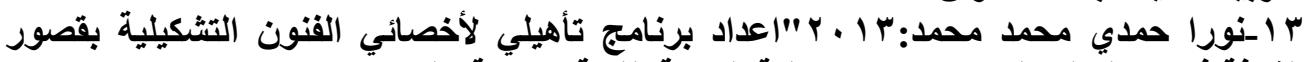

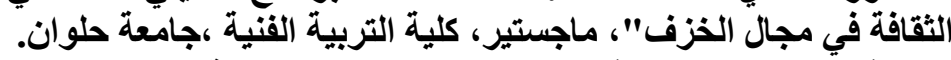

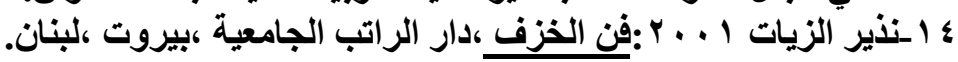

المراجع الأجنبية : المجية

1. austin-1995: apparel and textile production reference :book texas technical niversity home economics curriculum center.

2. EAed EL Fatah Hasan 2005: The Existing order of Development Society ,beers Al Ahram,10 May.www.ahram.org.eg.

3. www // http: Mukhallaf-com/ vb/show thread php?t=30402/copyright. 
ملخص البحث باللغة العربية

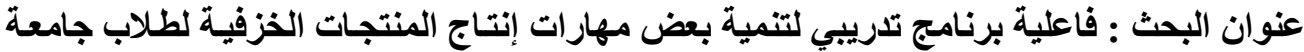

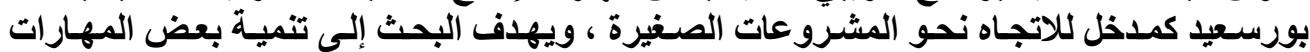

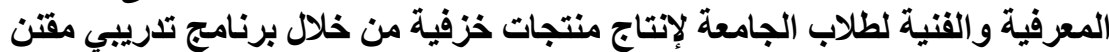

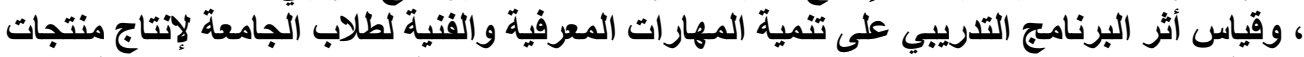

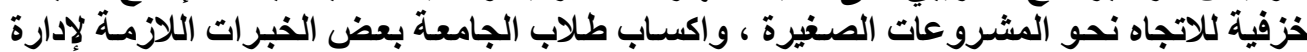

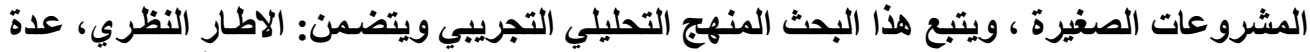

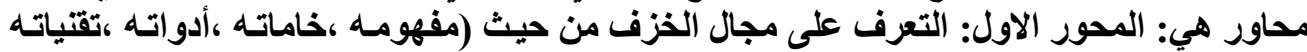

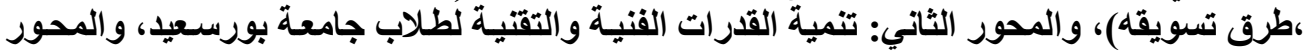

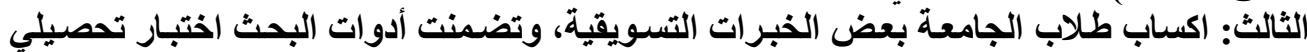

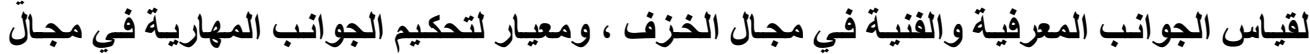

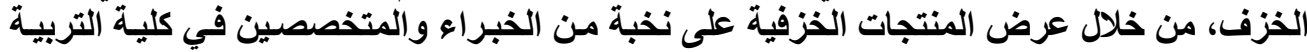

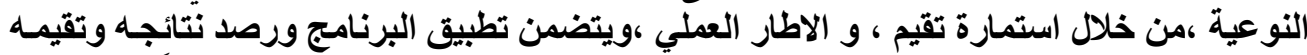

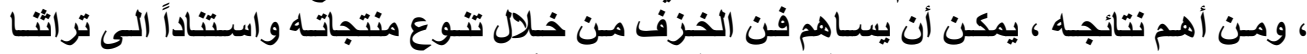

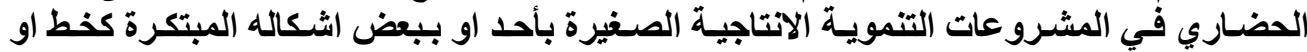

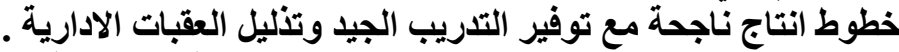
ملخص البحث باللغة الإنجليزية الأبل

The Effectiveness of the training program for the development of the skills of some of the production of ceramic products for thestudents of the university of port said as an entry pointto a trend towards small projects and The research aims to - disclosure of some of the important and effective breeding General Technical private porcelain roles in the service of society and the labor market, and the rehabilitation of young university colleges specialized technical and training on specialized technical areas and directing them toward the establishment of small businesses, and follows this research analytical method demo includes: a theoretical framework, several themes: First, identify the field of ceramics in terms of (concept, raw materials, tools, techniques, methods of marketing), second: the development of artistic and technical capabilities of the students of Port Said University, third: acquisition of university students some experience Altsuiqih ,ard ceramic products to a group of experts and specialists in the Faculty of Specific Education to measure how much of the program's objectives, through the form evaluate, and practical framework, and includes the implementation of the program and monitor the results, and hosted, and the most important results, can contribute to ceramic art through the diversity of its products and, based on our cultural heritage in one of the small development projects productivity or some forms of innovative line or successful production lines while providing good training and removing administrative obstacles... 